\title{
Longitudinal, Quantitative Assessment of Amyloid, Neuroinflammation, and Anti-Amyloid Treatment in a Living Mouse Model of Alzheimer's Disease Enabled by Positron Emission Tomography
}

\author{
Jun Maeda, ${ }^{1}$ Bin Ji, ${ }^{1}$ Toshiaki Irie, ${ }^{1}$ Takami Tomiyama, ${ }^{2}$ Masahiro Maruyama, ${ }^{1}$ Takashi Okauchi, ${ }^{1}$ \\ Matthias Staufenbiel, ${ }^{3}$ Nobuhisa Iwata, ${ }^{4}$ Maiko Ono, ${ }^{1}$ Takaomi C. Saido, ${ }^{4}$ Kazutoshi Suzuki, ${ }^{1}$ Hiroshi Mori, ${ }^{2}$ \\ Makoto Higuchi, ${ }^{1}$ and Tetsuya Suhara ${ }^{1}$ \\ ${ }^{1}$ Molecular Imaging Center, National Institute of Radiological Sciences, Chiba, Chiba 263-8555, Japan, ${ }^{2}$ Department of Neuroscience, Osaka City University \\ Graduate School of Medicine, Osaka, Osaka 545-8585, Japan, ${ }^{3}$ Novartis Institutes for Biomedical Research-Basel, CH-4002 Basel, Switzerland, and \\ ${ }^{4}$ Laboratory for Proteolytic Neuroscience, RIKEN Brain Science Institute, Wako, Saitama 351-0198, Japan
}

\begin{abstract}
We provide the first evidence for the capability of a high-resolution positron emission tomographic (PET) imaging system in quantitatively mapping amyloid accumulation in living amyloid precursor protein transgenic (Tg) mice. After the intravenous administration of $N$ - $\left[{ }^{11} \mathrm{C}\right]$ methyl-2-(4'-methylaminophenyl)-6-hydroxybenzothiazole (or $\left[{ }^{11} \mathrm{C}\right] \mathrm{PIB}$ for "Pittsburgh Compound-B") with high-specific radioactivity, the Tg mice exhibited high-level retention of radioactivity in amyloid-rich regions. PET investigation for Tg mice over an extended range of ages, including longitudinal assessments, demonstrated age-dependent increase in radioligand binding consistent with progressive amyloid accumulation. Reduction in amyloid levels in the hippocampus of Tg mice was also successfully monitored by multiple PET scans along the time course of anti-amyloid treatment using an antibody against amyloid $\beta$ peptide (A $\beta$ ). Moreover, PET scans with $\left[{ }^{18} \mathrm{~F}\right]$ fluoroethyl-DAA1106, a radiotracer for activated glia, were conducted for these individuals parallel to amyloid imaging, revealing treatment-induced neuroinflammatory responses, the magnitude of which intimately correlated with the levels of pre-existing amyloid estimated by $\left[{ }^{11} \mathrm{C}\right] \mathrm{PIB}$. It is also noteworthy that the localization and abundance of $\left[{ }^{11} \mathrm{C}\right] \mathrm{PIB}$ autoradiographic signals were closely associated with those of $\mathrm{N}$-terminally truncated and modified $\mathrm{A} \beta, \mathrm{A} \beta \mathrm{N} 3$-pyroglutamate, in Alzheimer's disease (AD) and $\mathrm{Tg}$ mouse brains, implying that the detectability of amyloid by $\left[{ }^{11} \mathrm{C}\right] \mathrm{PIB}$ positron emission tomography is dependent on the accumulation of specific $\mathrm{A} \beta$ subtypes. Our results support the usefulness of the small animal-dedicated PET system in conjunction with high-specific radioactivity probes and appropriate Tg models not only for clarifying the mechanistic properties of amyloidogenesis in mouse models but also for preclinical tests of emerging diagnostic and therapeutic approaches to AD.
\end{abstract}

Key words: Alzheimer's disease; amyloid; positron emission tomography; transgenic; immunotherapy; neuroinflammation

\section{Introduction}

The diagnosis of Alzheimer's disease (AD) does not become definite unless neuropathologists examine the autopsied brain and score $\mathrm{AD}$-characteristic amyloid lesions, which are known

Received Feb. 15, 2007; revised Aug. 27, 2007; accepted Aug. 29, 2007.

This work was supported in part by Grants-in-Aid for the Molecular Imaging Program and Scientific Research on Priority Areas, Research on Pathomechanisms of Brain Disorders 18023033 (H.M.), 182307 (N.I.), and 18023040 (M.H.) from the Ministry of Education, Culture, Sports, Science, and Technology, Japan. We thank Taisho Pharmaceutical (Tokyo, Japan) for providing DAA1123; Y. Matsuba, M. Sekiguchi, and K. Watanabe (RIKEN Brain Science Institute) for technical assistance; Dr. K. Yanai (Tohoku University, Sendai, Japan) and Dr. H. Toyama (Fujita Health University, Toyoake, Japan) for helpful advice; Drs. R. Innis and L. Cai (National Institutes of Health, Bethesda, MD) for critical discussions; Drs. J. Q. Trojanowski and V. M.-Y. Lee (University of Pennsylvania, Philadelphia, PA) for providing postmortem human brain tissues; and Dr. K. H. Ashe (University of Minnesota, Minneapolis, MN) for providing Tg2576 mice.

The authors declare no competing financial interests.

Correspondence should be addressed to Dr. Makoto Higuchi, Molecular Imaging Center, National Institute of Radiological Sciences, 4-9-1 Anagawa, Inage-ku, Chiba, Chiba 263-8555, Japan. E-mail: mhiguchi@nirs.go.jp.

DOI:10.1523/JNEUROSCI.0673-07.2007

Copyright $\odot 2007$ Society for Neuroscience ～0270-6474/07/2710957-12\$15.00/0 as senile plaques and neurofibrillary tangles that are mechanistically implicated in neurodegenerative processes. Meanwhile, attempts to noninvasively visualize amyloid deposition in human brains using positron emission tomography have been made by developing imaging agents capable of reacting with amyloid fibrils (Sair et al., 2004; Nichols et al., 2006), among which $N$ - $\left[{ }^{11} \mathrm{C}\right]$ methyl-2-(4'-methylaminophenyl)-6hydroxybenzothiazole (or $\left[{ }^{11} \mathrm{C}\right] \mathrm{PIB}$ for "Pittsburgh Compound-B") is the most intensively evaluated in human positron emission tomographic (PET) studies (Klunk et al., 2004; Price et al., 2005; Engler et al., 2006; Mintun et al., 2006). The ability of $\left[{ }^{11} \mathrm{C}\right] \mathrm{PIB}$ to detect amyloid in patients with mild cognitive impairment (MCI) (Price et al., 2005) and in a nondemented population (Mintun et al., 2006) has suggested the potential of this probe for identifying the AD pathology antecedent to the clinical onset. Meanwhile, notable accumulation of this and other amyloid tracers in some amyloid-unrelated 
regions of human brains (Shoghi-Jadid et al., 2002; Klunk et al., 2004; Verhoeff et al., 2004) might arouse controversy over the specificity of this imaging technique for neurodegenerative pathologies. To efficiently exploit radioligands suitable for the purpose of establishing an early and sensitive marker of brain amyloidosis, or an objective measure of neuropathological severity in the progression of $\mathrm{AD}$, preclinical screening of the candidate compounds by using in vivo systems is highly requisite. Such systems could also promote a proof-ofconcept study on novel treatments (Scarpini et al., 2003) capable of suppressing neurotoxic amyloid aggregates.

There have been numerous lines of transgenic $(\mathrm{Tg})$ mice that overexpress human mutant amyloid precursor protein (APP) causative of familial $\mathrm{AD}$ and recapitulate plaque pathology in $\mathrm{AD}$ brains (Hsiao et al., 1996; Sturchler-Pierrat et al., 1997). As shown by several investigations (Bacskai et al., 2003; Higuchi et al., 2005; Hintersteiner et al., 2005), use of fluorescent and magnetic resonance imaging (MRI) probes offers methodologies to capture brain amyloid in these animals. However, optical and MRI tracers need to be administered to achieve $\sim 1 \mu \mathrm{M}$ levels, which is much higher than that required for PET tracers $(\sim 1 \mathrm{nM}$ levels) and thus might influence the course of amyloid pathogenesis particularly in longitudinal multiscan experiments. Although improvements of both detection instruments and imaging agents to increase sensitivity of these modalities are ongoing, visualization of mouse amyloid by positron emission tomography would open a new avenue for monitoring the dynamic status of amyloid deposition in living brains with minimal interference. Additional major benefits of PET imaging are also offered by the flexibility in designing imaging probes for specific purposes, allowing us to target different molecules of interest in the same individuals. This is of pivotal importance in the mechanistic evaluation of amyloid $\beta$ peptide $(A \beta)$ immunization and other related anti-amyloid treatments (Dodel et al., 2003), because a PET ligand for peripheral benzodiazepine receptor (PBR), termed $\left[{ }^{18} \mathrm{~F}\right]$ fluoroethyl(FE)-DAA1106, which we have recently developed for capturing glial activation (Zhang et al., 2004), can be used in combination with amyloid probes to longitudinally assess the contribution of neuroinflammation to therapeutic and adverse effects.

The aim of this study was to prove the power of animal PET technology in pursuit of amyloidogenesis and evaluation of emerging anti-amyloid treatments. Two independent groups demonstrated that $\left[{ }^{11} \mathrm{C}\right]$ PIB PET data in brains of mice developing abundant plaque lesions were virtually indistinguishable from those in wild-type (WT) mouse brains (Klunk et al., 2005; Toyama et al., 2005). A possible reason for the insensitivity of PET imaging in capturing mouse amyloid may lie in the paucity of high-affinity binding sites for the radioligand in APP Tg mouse brains compared with AD brains (Klunk et al., 2005). Thus, we have overcome this problem by administering $\left[{ }^{11} \mathrm{C}\right] \mathrm{PIB}$ synthesized with high specific radioactivity and consequently less nonradioactive competitors, which facilitates binding of the radioactive compound to the target molecule. Furthermore, advantages of in vivo PET measurement of amyloid have been reinforced by paralleling assays using $\left[{ }^{11} \mathrm{C}\right] \mathrm{PIB}$ and $\left[{ }^{18} \mathrm{~F}\right] \mathrm{FE}-\mathrm{DAA} 1106$ to follow the course of $\mathrm{A} \beta$ immunization.

\section{Materials and Methods}

Animals. The animals were maintained and handled in accordance with the recommendations of the National Institutes of Health and institutional guidelines of the National Institute of Radiological Sciences. All animal experiments conducted here were approved by the Animal Ethics Committee of the National Institute of Radiological Sciences.
Tg mice termed APP23 mice, which overexpress the Swedish doubly mutant APP751 under the control of a neuron-specific Thy-1 promoter element, were generated as described in detail previously (SturchlerPierrat et al., 1997). The strain was maintained on a C57BL/6J background, and female mice were used for the experiments. Female non- $\mathrm{Tg}$ littermates were also used as WT controls.

Generation of MRI template. A 12-month-old C57BL/6J mouse was lethally anesthetized by pentobarbital. The mouse head was embedded in $3 \%$ aqueous agarose and scanned by a 9.4 tesla AVANCE 400WB imaging spectrometer (Bruker BioSpin, Ettlingen, Germany), as described previously (Higuchi et al., 2005). Coronal T2-weighted MR images were acquired by using a three-dimensional (3D) fast spin-echo sequence with the following imaging parameters: echo time, $5.5 \mathrm{~ms}$; repetition time, $3000 \mathrm{~ms}$; RARE (rapid acquisition with relaxation enhancement) factor, 32; field of view (FOV), $20 \times 20 \times 25 \mathrm{~mm}^{3}$; matrix dimensions, $256 \times$ $512 \times 60$; nominal resolution, $78 \times 39 \times 417 \mu \mathrm{m}$. The MRI data were used as an anatomical template for the subsequent PET studies.

Ex vivo autoradiography and histochemical examinations. Ex vivo assessment of regional brain radioactivity concentration was conducted in $\mathrm{Tg}$ and WT mice. The animals were given injections of $\left[{ }^{11} \mathrm{C}\right] \mathrm{PIB}$ $(18.5-37 \mathrm{MBq})$ in the tail vein under anesthesia with $1-1.5 \%(\mathrm{v} / \mathrm{v})$ isoflurane in air $(2 \mathrm{ml} / \mathrm{min}$ flow rate). After the tracer injection, the mice were killed by decapitation, and brains were immediately removed and frozen in powdered dry ice. Frozen brain tissue was coronally cut into $20-\mu \mathrm{m}-$ thick sections by HM560 cryotome (Carl Zeiss, Jena, Germany). The slices were subsequently dried under warm blowing air and contacted to an imaging plate (FujiFilm, Tokyo, Japan) for $2 \mathrm{~h}$. The imaging plate data were scanned by a BAS5000 system (FujiFilm). The intensity of radioactive signals was measured by Multi Gauge software (FujiFilm). The radiotracer uptake was calculated as percentage of injected dose (\%ID) per tissue volume $(\mathrm{ml})$ uncorrected $(\% \mathrm{ID} / \mathrm{ml})$ and corrected $(\% \mathrm{ID} \cdot \mathrm{kg} / \mathrm{ml})$ for body weight.

After the radioactivity was allowed to decay, brain sections used for the autographic assay were fixed with $4 \%$ paraformaldehyde in PBS and stained with either $0.01 \%$ (E,E)-1-fluoro-2,5-bis(3-hydroxycarbonyl-4hydroxy)styrylbenzene (FSB; Dojindo Laboratories, Kumamoto, Japan) (Sato et al., 2004; Higuchi et al., 2005), a fluorinated analog of the well characterized amyloid-binding compound termed X-34 (Styren et al., 2000; Ikonomovic et al., 2006), or 0.01\% BTA-1 (Sigma-Aldrich, St. Louis, MO) in 50\% ethanol, as described previously (Sato et al., 2004; Higuchi et al., 2005). The FSB-stained samples were also immunostained with a mouse monoclonal anti-A $\beta$ antibody (6E10; Signet Laboratories, Dedham, MA).

Radiochemical synthesis. The radiosynthesis of $\left[{ }^{11} \mathrm{C}\right] \mathrm{PIB}$ was instituted by using protected precursor and high-specific radioactivity $\left[{ }^{11} \mathrm{C}\right]$ methyl triflate. Briefly, $\left[{ }^{11} \mathrm{C}\right]$ methyl iodide was synthesized with high specific radioactivity by single-pass reaction of $\left[{ }^{11} \mathrm{C}\right]$ methane with $\mathrm{I}_{2}$ (Noguchi and Suzuki, 2003; Zhang and Suzuki, 2005). Subsequently, $\left[{ }^{11} \mathrm{C}\right]$ methyl triflate was synthesized for radiochemical reaction and was transferred into $300 \mu \mathrm{l}$ of anhydrous acetone containing $1 \mathrm{mg}$ of 2-(4aminophenyl)-6-methoxymethoxybenzothiazole. After the trapping was finished, a solution of methanol/HCl (500 $\mu \mathrm{l}, 2: 1$ methanol/concentrated $\mathrm{HCl}$ ) was used to remove the protective group, and the reaction was heated at $100^{\circ} \mathrm{C}$ for $2 \mathrm{~min}$. HPLC purification was performed on a YMC-Pack ODS-AQ-324 column $(10 \mathrm{~mm}$ ID $\times 300 \mathrm{~mm}$ ) (YMC, Kyoto, Japan) using a mobile phase of 50:50 acetonitrile/ $\mathrm{H}_{2} \mathrm{O}$ at a flow rate of 6.0 $\mathrm{ml} / \mathrm{min}$. The radioactive fraction corresponding to $\left[{ }^{11} \mathrm{C}\right] \mathrm{PIB}$ was collected in a sterile flask containing $75 \mu \mathrm{l}$ of polysorbate 80 and $300 \mu \mathrm{l}$ of ethanol, evaporated to dryness under vacuum, redissolved in $10 \mathrm{ml}$ of sterile normal saline, and passed through a $0.22 \mu \mathrm{m}$ Millipore (Billerica, MA) FG filter for quality analysis and animal experiments. The radiochemical purity of the resultant compound was $97.6 \pm 0.18 \%$, and the specific radioactivity was $291 \pm 10.3 \mathrm{GBq} / \mu \mathrm{mol}$ at the end of synthesis. Nonradioactive PIB and the precursor used for the radiosynthesis were custom made by KNC Laboratories (Kobe, Japan).

$\left[{ }^{18} \mathrm{~F}\right] \mathrm{FE}-\mathrm{DAA} 1106$, a PET ligand for PBR, was radiosynthesized using its desmethyl precursor, DAA1 123 (generously provided by Taisho Pharmaceutical, Tokyo, Japan), as described previously in detail (Zhang et al., 2004). The radiochemical purity of the end product exceeded $95 \%$, and 
the specific radioactivity was $120 \pm 20.5 \mathrm{GBq} / \mu \mathrm{mol}$ at the end of synthesis.

Small-animal PET imaging. All PET scans were performed using a micro-PET Focus 220 animal scanner (Siemens Medical Solutions USA, Knoxville, TN) designed for rodents and small monkeys, which provides 95 transaxial slices $0.815 \mathrm{~mm}$ (center-to-center) apart, a $19.0 \mathrm{~cm}$ transaxial FOV, and a $7.6 \mathrm{~cm}$ axial FOV (Tai et al., 2005). Before the scans, the mice were anesthetized with $1.5 \%(\mathrm{v} / \mathrm{v})$ isoflurane. After transmission scans for attenuation correction using a ${ }^{68} \mathrm{Ge}-{ }^{68} \mathrm{Ga}$ point source, emission scans were acquired for $60 \mathrm{~min}$ in a 3D list mode with an energy window of $350-750 \mathrm{keV}$, immediately after the intravenous injection of $\left[{ }^{11} \mathrm{C}\right] \mathrm{PIB}(30.0 \pm 6.8 \mathrm{MBq})$ or $\left[{ }^{18} \mathrm{~F}\right] \mathrm{FE}-\mathrm{DAA} 1106(15.3 \pm 4.6 \mathrm{MBq})$. All list-mode data were sorted into 3D sinograms, which were then Fourier rebinned into two-dimensional sinograms (frames: $10 \times 1,8 \times 5$, and $1 \times 10 \mathrm{~min}$ ). Summation images from 0 to $30 \mathrm{~min}$ and from 30 to $60 \mathrm{~min}$ after $\left[{ }^{11} \mathrm{C}\right] \mathrm{PIB}$ injection were reconstructed with maximum a posteriori (MAP) reconstruction, and dynamic images were reconstructed with filtered backprojection using a $0.5 \mathrm{~mm}$ Hanning's filter. Volumes of interest were placed on multiple brain areas using PMOD image analysis software (PMOD Group, Zurich, Switzerland) with reference to the MRI template.

To assess the capability of the present imaging system in monitoring the effects of anti-amyloid treatment, we scanned WT and Tg mice at multiple time points during the time course of passive $A \beta$ immunization. Intrahippocampal injection of anti- $\mathrm{A} \beta$ antibody was performed based on established procedures (Wilcock et al., 2003). Three Tg mice aged 20, 21 , and 24 months and two WT mice aged 5 and 8 months were anesthetized with $1.5 \%(\mathrm{v} / \mathrm{v})$ isoflurane and placed in a stereotactic frame (Narishige, Tokyo, Japan). Using a 30 gauge needle connected to a $10 \mu \mathrm{l}$ Hamilton (Reno, NV) syringe, $1 \mu \mathrm{l}$ of mouse monoclonal antibody against the N-terminal portion of $A \beta(6 \mathrm{E} 10,1 \mathrm{mg} / \mathrm{ml}$; Signet Laboratories) and vehicle alone were injected into the right and left hippocampi, respectively (stereotactic coordinates: anteroposterior, $-2.8 \mathrm{~mm}$; mediolateral, $2.0 \mathrm{~mm}$; dorsoventral, $3.0 \mathrm{~mm}$ from the bregma), over $2 \mathrm{~min}$. The needle was thereafter raised by $1 \mathrm{~mm}$, and injection of $1 \mu \mathrm{l}$ of the solution was repeated. A total of six PET scans using $\left[{ }^{11} \mathrm{C}\right] \mathrm{PIB}$ and $\left[{ }^{18} \mathrm{~F}\right]$ FE-DAA1106 (two tracers $1-2 \mathrm{~d}$ apart) were performed for each mouse at 1 or 2 weeks before and 1 and 2 weeks after the antibody injection. Mouse brains were thereafter dissected and histochemically examined with FSB and rabbit polyclonal antibody against ionized calcium-binding adapter molecule 1 (Iba-1; Wako Pure Chemicals, Osaka, Japan) recognizing microglia.

The effects of the ID and specific radioactivity of $\left[{ }^{11} \mathrm{C}\right] \mathrm{PIB}$ on the sensitivity of amyloid detection were also studied. Three Tg mice (age, $19.7 \pm 1.5$ months) underwent two PET scans $1-2$ weeks apart, each conducted with either high-dose $(31.2 \pm 5.1 \mathrm{MBq})$, high-specific radioactivity ( $\sim 200 \mathrm{GBq} / \mu \mathrm{mol})$ or low-dose $(3.4 \pm 1.1 \mathrm{MBq})$, middle-specific radioactivity $(\sim 20 \mathrm{GBq} / \mu \mathrm{mol})$ tracers. In the middle-specific radioactivity experiment, two mice received $\left[{ }^{11} \mathrm{C}\right] \mathrm{PIB}$, which was kept at room temperature until its specific radioactivity had dropped to the assigned value, and one mouse was given an injection of the radiotracer $(200 \mu \mathrm{l})$ mixed with $0.5 \mu \mathrm{g}$ of cold PIB dissolved in $20 \mu \mathrm{l}$ of dimethylsulfoxide (DMSO). Moreover, the influence of varying the specific radioactivity alone was examined by scanning one 18-month-old Tg mouse administered with high $(\sim 200 \mathrm{GBq} / \mu \mathrm{mol})$ and middle $(\sim 20 \mathrm{GBq} / \mu \mathrm{mol})$ specific radioactivities and another 20 -month-old Tg mouse with high, middle, and low $(\sim 0.2 \mathrm{GBq} / \mu \mathrm{mol})$ specific radioactivities. The middle- and lowspecific radioactivity tracers were prepared by adding 0.5 and $50 \mu \mathrm{g}$ of cold PIB, respectively, in $20 \mu \mathrm{l}$ of DMSO to the radiotracer solution (200 $\mu \mathrm{l})$.

In vitro binding of $\left[{ }^{11} \mathrm{C}\right] \mathrm{PIB}$ to amyloid plaques and immunohistochemistry for $\mathrm{N}$ - and C-terminal heterogeneity of $A \beta$. APP23 Tg mice at 23-31 months of age ( $n=5$; age, $28.6 \pm 1.47$ months) were killed by decapitation, and the brains were frozen and cut into $20-\mu \mathrm{m}$-thick coronal sections by HM560 cryotome (Carl Zeiss). The sections were mounted on slide glass (Matsunami Glass, Osaka, Japan) and stored at $-80^{\circ} \mathrm{C}$ pending analyses. Similarly, brain sections were obtained from a 23-monthold mouse expressing Swedish mutant APP under the control of hamster prion protein promoter, termed $\mathrm{Tg} 2576$ (Hsiao et al., 1996), and an 8-month-old double-Tg mouse generated by crossbreeding Tg2576 mice with mice expressing A260V mutant presenilin-1 (PS-1) (Kametani et al., 2004) under the control of prion protein promoter. In addition, cortical brain sections were generated from the brain of a patient with definite AD (generously provided by Drs. J. Q. Trojanowski and V. M.-Y. Lee, University of Pennsylvania, Philadelphia, PA). Brain sections were incubated in $50 \mathrm{~mm}$ Tris- $\mathrm{HCl}$ buffer, $\mathrm{pH} 7.4$, containing $5 \%$ ethanol and $\left[{ }^{11} \mathrm{C}\right] \mathrm{PIB}$ (37 MBq/L, $\sim 200 \mathrm{pm}$ ) at room temperature for $60 \mathrm{~min}$. Nonspecific binding was determined in the presence of $10 \mu \mathrm{M}$ nonradioactive PIB. After the reaction, the samples were rinsed with ice-cold Tris-HCl buffer twice for $2 \mathrm{~min}$ and dipped into ice-cold water for $10 \mathrm{~s}$. Autoradiograms were obtained as in the above-mentioned ex vivo autoradiography procedure.

After the radioactivity was allowed to decay, brain sections used for the autographic assay were fixed with $4 \%$ paraformaldehyde in PBS and either immunostained with a rabbit polyclonal antibody against $\mathrm{A} \beta \mathrm{N} 3$ pyroglutamate, N3(pE) (Saido et al., 1995), or doubly immunolabeled with a rabbit polyclonal antibody against $\mathrm{A} \beta 40$, Ter40, and a mouse monoclonal antibody against $\mathrm{A} \beta 42,11 \mathrm{C}$. Immunohistochemistry for subadjacent sections was also performed using a rabbit polyclonal antibody against the unmodified N terminus of A $\beta$, N1D (Saido et al., 1995); a mouse monoclonal antibody against $\mathrm{A} \beta 40,6 \mathrm{~A}$; and a rabbit polyclonal antibody against $\mathrm{A} \beta 42$, Ter42.

Statistical analyses. All statistical examinations in the present study were performed by SPSS (Chicago, IL) software. For comparisons of radiotracer uptake among regions and between WT and Tg mice, we performed two-way, repeated-measures ANOVA. Correlations of two parameters were tested by the $t$ statistic.

\section{Results}

\section{Plaque labeling with intravenously injected $\left[{ }^{11} \mathrm{C}\right] \mathrm{PIB}$}

As a consequence of our continuous efforts to reduce nonradioactive byproducts in automated radiosynthesis and to efficiently use the single-pass $\mathrm{I}_{2}$ method for generation of the reactive ${ }^{11} \mathrm{C}$ labeled precursor (Suzuki et al., 1985; Noguchi and Suzuki, 2003; Zhang and Suzuki, 2005), we were able to synthesize $\left[{ }^{11} \mathrm{C}\right] \mathrm{PIB}$ with a specific radioactivity of $291 \pm 10.3 \mathrm{GBq} / \mu \mathrm{mol}$ at the end of synthesis, which much exceeded those of previous small-animal PET studies (37-118 GBq/ $\mu \mathrm{mol}$ ) (Klunk et al., 2005; Toyama et al., 2005), and administered it to mice immediately after the radiosynthesis ( $>200 \mathrm{GBq} / \mu \mathrm{mol}$ at the time of injection). We first assessed the pharmacokinetic profile of intravenously injected $\left[{ }^{11} \mathrm{C}\right] \mathrm{PIB}$ in the WT mouse brains by ex vivo autoradiography (supplemental Fig. $1 A, B$, available at www.jneurosci.org as supplemental material). Although the radiotracer accumulated rapidly in all brain areas, the intensity at 5 and 30 min after injection was relatively high in the subcortical white matter, basal ganglia, thalamus, and pons, similar to the findings in human PET studies for normal controls (Klunk et al., 2004; Price et al., 2005; Mintun et al., 2006). These amyloid-unrelated signals were attenuated thereafter, and no apparent regional differences in radioactivity were noted at $60 \mathrm{~min}$ after the tracer injection (supplemental Fig. $1 A, B$, available at www.jneurosci.org as supplemental material). In addition, no overt effects of age on the radiotracer level at 30 min were observed (supplemental Fig. 1C, available at www. jneurosci.org as supplemental material).

Ex vivo autoradiography of the brains of APP Tg mice at 30 min after the administration of $\left[{ }^{11} \mathrm{C}\right] \mathrm{PIB}$ yielded high-contrast maps of putative plaques that were progressively increased with age (Fig. $1 A$ ). Although faint signals were detected in the white matter of both WT and Tg mice, clusters of punctate labeling were found exclusively in the Tg neocortex and hippocampus. Indices of the radiotracer accumulation, both uncorrected (\%ID/ $\mathrm{ml})$ and corrected $(\% \mathrm{ID} \cdot \mathrm{kg} / \mathrm{ml})$ for body weight, were particularly increased in these regions of the 21-month-old Tg mice 
compared with the age-matched WT mice (Fig. $1 B, C$ ). The levels of tracer binding in the hippocampus and neocortex were also quantified by calculating the ratio of the regional radioactivity against the cerebellum, and a significant difference in the ratio between the two genotypes was observed (Fig. 1D).

Fluorescence staining of the brain sections used for ex vivo autoradiography demonstrated excellent colocalization of radiotracer labeling with FSB-positive and $\mathrm{A} \beta$-immunoreactive amyloid plaques developed in the Tg mice (Fig. $1 E$ ). Detailed examination revealed that not only mature dense-core plaques but also small compact amyloid deposits produced increased radiotracer signals (Fig. $1 F$, top). It is also noteworthy that the intravenously injected radiotracer accumulated at a high level in the cerebrovascular amyloid (Fig. $1 \mathrm{~F}$, bottom). In the Tg mice aged 16-31 months, tracer uptakes in the hippocampus and neocortex were elevated in tight association with age, in clear contrast with the poor correlation between age and cerebellar radiotracer level (Fig. 1G). We also found a significantly close correlation between the load of FSB-stained amyloid and the level of $\left[{ }^{11} \mathrm{C}\right] \mathrm{PIB}$ uptake in the hippocampus and neocortex of these $\mathrm{Tg}$ mice (Fig. 1H), suggesting the ability of $\left[{ }^{11} \mathrm{C}\right] \mathrm{PIB}$ to quantitatively measure the amyloid burden in the living brain.

\section{Visualization of amyloid deposition in living APP Tg mice by micro-positron emission tomography}

We subsequently applied small-animaldedicated PET and MRI systems to precise mapping of radioligand in living mouse brains. MAP reconstruction of the data obtained by the micro-PET Focus 220 animal scanner (Siemens Medical Solutions USA) offered high-resolution images illustrating the distribution of $\left[{ }^{11} \mathrm{C}\right] \mathrm{PIB}$ in the WT mouse brain (supplemental Fig. 2A, available at www.jneurosci.org as supplemental material). PET images coregistered with MRI space generated by a 9.4 tesla AVANCE 400WB imaging spectrometer (Bruker BioSpin) indicated high-level uptake of the tracer in the thalamus, pons, and cerebellar white matter, followed by a lower level in the basal ganglia, early in the emission scan. Such regional differences were gradually reduced and had almost disappeared at $60 \mathrm{~min}$ after the tracer injection (supplemental Fig. $2 A-C$, available at www.jneurosci.org as supplemental material).

Consistent with our ex vivo findings, radioactive signals in the PET images at
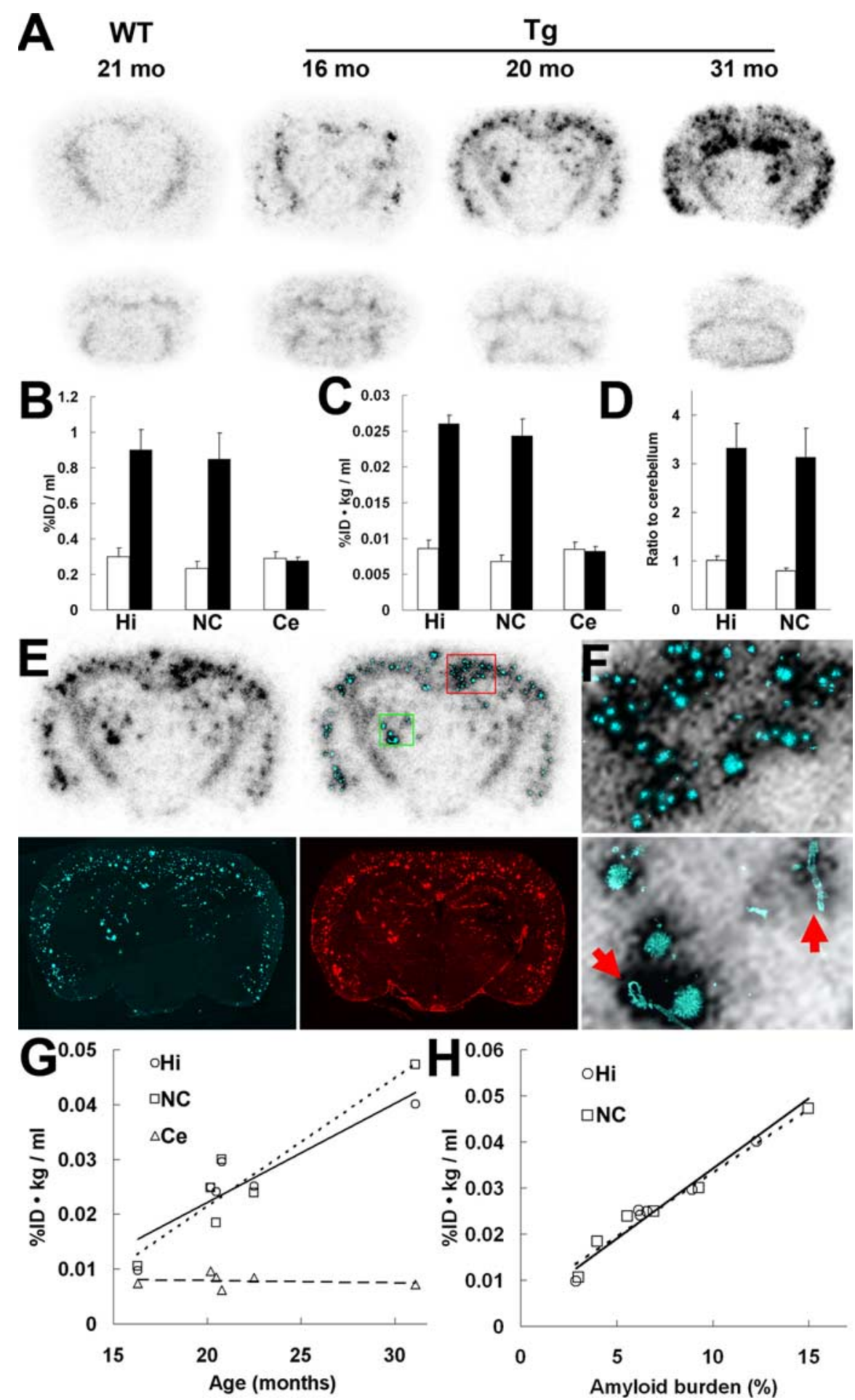

Figure 1. Amyloidosis-associated accumulation of $\left[{ }^{11} \mathrm{C}\right] \mathrm{PIB}$ in ex vivo autoradiographic analysis of APP Tg mouse brains. $\boldsymbol{A}$, Binding of the radiotracer to putative amyloid plaques primarily located in the neocortex and hippocampus of $\mathrm{Tg}$ mice. Images were obtained $30 \mathrm{~min}$ after tracer administration. Top and bottom panels represent coronal images at 2 and $7 \mathrm{~mm}$ posterior to the bregma, respectively. mo, Month. $\boldsymbol{B}, \boldsymbol{C}$, Levels of radiotracer at $30 \mathrm{~min}$ after injection in the hippocampus, neocortex, and cerebellum of APP Tg (filled bars; $n=4$; age, $21.0 \pm 0.51$ months) and age-matched WT (open bars; $n=5$; age, $19.0 \pm 1.0$ months) mice, indicated as $\% \mathrm{ID} / \mathrm{ml}(\boldsymbol{B})$ and $\% \mathrm{ID} \cdot \mathrm{kg} / \mathrm{ml}(\boldsymbol{C})$. There were significant main effects of brain regions and genotypes on both $\% \mathrm{ID} / \mathrm{ml}$ (region, $F_{(2,12)}=16.6, p<0.01$; genotype, $F_{(1,6)}=14.7, p<0.01$; 2-way, repeated-measures ANOVA) and $\% \mathrm{ID} \cdot \mathrm{kg} / \mathrm{ml}$ (region, $F_{(2,12)}=33.9, p<0.001 ;$ genotype, $F_{(1,6)}=54.3, p<0.001 ; 2$-way, repeated-measures ANOVA). $\boldsymbol{D}$, Target-to-cerebellum ratio of radiotracer levels in the hippocampus and neocortex. The ratio was significantly increased in $\mathrm{Tg}$ mice (filled bars) relative to WT mice (open bars) (significant main effect of genotype; $F_{(1,6)}=17.0 ; p<0.01 ; 2$-way, repeatedmeasures ANOVA). $E$, Coronal brain section (at $2 \mathrm{~mm}$ posterior to the bregma) obtained from a 20.2-month-old Tg mouse. An ex vivo autoradiographic image (top left) depicts radiotracer distribution at $30 \mathrm{~min}$ after intravenous administration. The same sections were subsequently stained with a fluorescent amyloid dye, FSB (bottom left). Merged images (top right) explicitly demonstrate intense accumulation of radiotracer in close association with amyloid plaques. The sections were finally immuno- 


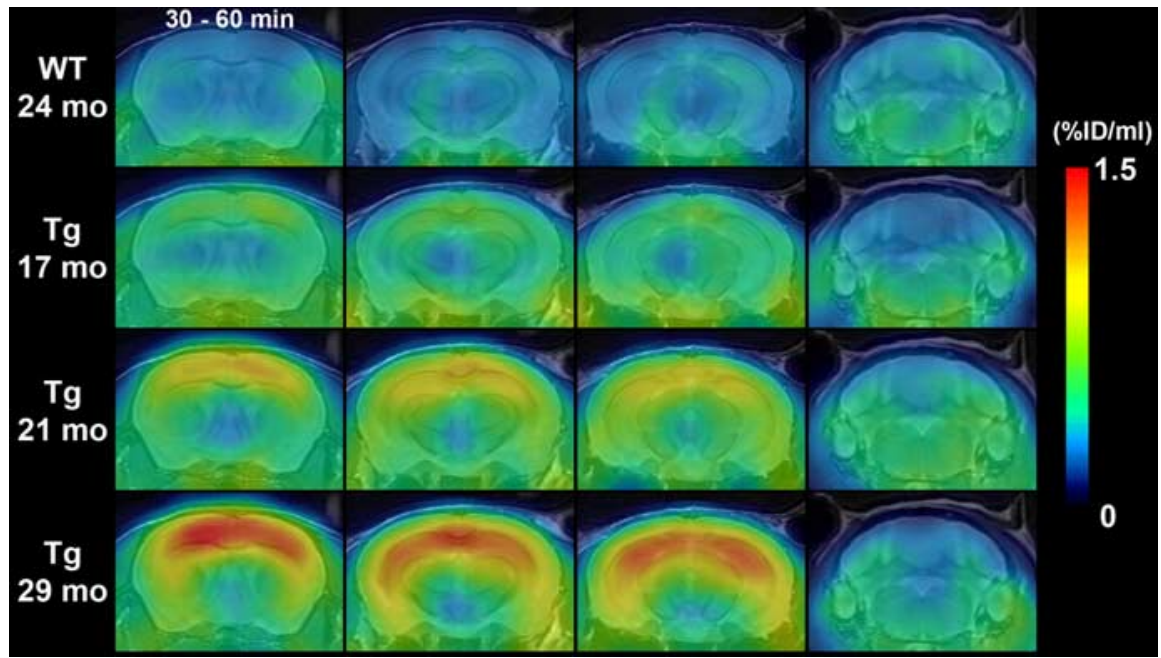

Figure 2. In vivo detection of amyloid plaques in APP Tg mice at different ages. PET images were generated by averaging dynamic scan data at 30-60 min after administration of $\left[{ }^{11} \mathrm{C}\right] \mathrm{PIB}$ and were overlaid on the MRI template. From left to right, panels represent coronal images at $0,2,3$, and $7 \mathrm{~mm}$ posterior to the bregma. mo, Month.

30-60 min after the administration of $\left[{ }^{11} \mathrm{C}\right] \mathrm{PIB}$ were notably intensified in the hippocampus and neocortex of Tg mice (Fig. 2). The contrast between the WT and $\mathrm{Tg}$ mice was recognizable at 17 months of age and became more pronounced with increasing age. Unlike amyloid-rich regions, the cerebellum and pons consistently exhibited low-level signals in both genotypes. The cerebellar time-radioactivity curves corrected for body weight $(\% \mathrm{ID} \cdot \mathrm{kg} / \mathrm{ml})$ in 21 -month-old $\mathrm{Tg}$ and age-matched WT mice resembled each other (Fig. 3A), whereas those in the hippocampus (Fig. 3B) and neocortex (Fig. $3 C$ ) of Tg mice were clearly distinguishable from those of WT mice. It is notable that Tg mice exhibited increased levels of radiotracer retention determined as $\% \mathrm{ID} \cdot \mathrm{kg} / \mathrm{ml}$ compared with WT mice, notwithstanding the fact that the average body weight of $\mathrm{Tg}$ mice was significantly smaller than that of WT mice (25.7 g vs $31.7 \mathrm{~g} ; p<0.05, t$ test). The difference in radiotracer binding between Tg and WT mice was more explicitly displayed by plotting target-to-cerebellum ratios of the radioactivity over the scan time (Fig. $3 D, E$ ). We also examined the radioligand binding by calculating the binding potential (combined measure of density of target molecules and affinity of the tracer) using the cerebellar time-radioactivity curve as a reference (Fig. $3 F$ ). The binding potential values estimated by the simplified reference tissue model (Lammertsma et al., 1996) were prominently increased in the hippocampus and neocortex of $\mathrm{Tg}$

\footnotetext{
$\leftarrow$

stained with anti-A $\beta$ antibody $6 \mathrm{E} 10$, and spatial concordance between intense radioactive signals and $A \beta$-immunoreactive plaques were confirmed (bottom right). $\boldsymbol{F}$, High-power view of the autoradiographic image overlaid on FSB fluorescence in the neocortical (top panel) and thalamic (bottom panel) regions of the mouse brain shown in $\boldsymbol{E}$ (indicated by red and green squares, respectively). Arrows indicate vascular amyloid. $\mathbf{G}$, Age-associated increase in radiotracer binding in the hippocampus and neocortex of Tg mice ( $n=6$; age, $21.9 \pm 2.0$ months; range, 16.3-31.1 months). The correlation between age and radiotracer binding was significant in these plaque-bearing regions (hippocampus, $R^{2}=0.76$ and $p<0.01$ by $t$ test; neocortex, $R^{2}=0.77$ and $p<0.01$ by $t$ test), in contrast to the cerebellar levels of the tracer unrelated to age $\left(R^{2}=0.08 ; p>0.05, t\right.$ test). $\boldsymbol{H}$, Scatterplot of radiotracer uptake versus amyloid burden (indicated as percentage of target brain area) in the hippocampus and neocortex of Tg mice ( $n=6$; age, $21.9 \pm 2.0$ months; range, 16.3-31.1 months), with the correlation of the two parameters being statistically significant in both regions $\left(R^{2}=0.96\right.$ and 0.97 for hippocampus and neocortex, respectively; $p<0.01, t$ test). Solid, dotted, and dashed lines in the graphs represent regressions for the hippocampus, neocortex, and cerebellum, respectively. Error bars represent SE. Hi, Hippocampus; NC, neocortex; Ce, cerebellum.
}

mice compared with those in WT controls. A similar result was obtained by determining the binding potential based on the multilinear reference tissue model (Ichise et al., 2003) (data not shown).

The relationship between binding potential and amyloid accumulation was more extensively analyzed by collecting PET data from $\mathrm{Tg}$ mice aged 17-29 months (Fig. $4 A, B$ ). Radiotracer binding in the hippocampus and neocortex was significantly correlated with age, in line with the progression of amyloidogenesis in these areas. It is of particular significance that the time course of plaque formation in five Tg mice could be pursued by longitudinal PET experiments (Fig. $4 A, B$, red lines and symbols; representative image data are shown in Fig. 4C,D).

We also compared binding potential values determined by the simplified reference tissue model with distribution volume ratios calculated by Logan's graphical analysis with substitution of cerebellar data in place of arterial input function (Logan et al., 1996) to validate the use of reference tissue models for estimation of radiotracer binding in the mouse brains. The data obtained from all mice undergoing $\left[{ }^{11} \mathrm{C}\right]$ PIB PET scans demonstrated that the [binding potential +1 ] values were highly consistent with the distribution volume ratios for a reasonably broad range of radiotracer accumulation levels (supplemental Fig. 3, available at www.jneurosci.org as supplemental material), and thus both compartmental and graphical methods are considered to be applicable to the kinetic analysis for $60 \mathrm{~min}$ dynamic $\left[{ }^{11}\right.$ C]PIB PET data in mice.

The potential utility of the present imaging system in assessing amyloid levels along the time course of anti-amyloid treatment was also supported by our multiscan, multitracer PET analysis of $\mathrm{Tg}$ mice before and 1 and 2 weeks after intrahippocampal injection of anti- $\mathrm{A} \beta$ antibody for the purpose of passive $\mathrm{A} \beta$ immunization (Wilcock et al., 2003). PET scans of the same individual with [ $\left.{ }^{11} \mathrm{C}\right] \mathrm{PIB}$ clearly indicated progressive decline of hippocampal amyloid triggered by the local administration of anti- $\mathrm{A} \beta$ antibody (Fig. 5A), in clear contrast to the prominent neuroinflammation induced by injected antibody, as monitored by positron emission tomography with $\left[{ }^{18} \mathrm{~F}\right] \mathrm{FE}-\mathrm{DAA} 1106$ (Fig. $5 B$ ). In vivo radiolabeling of amyloid in the antibody-injected hippocampus, estimated as the binding potential for $\left[{ }^{11} \mathrm{C}\right] \mathrm{PIB}$, was consistently reduced over the time course in all three treated mice (Fig. 5C). Similarly, a notable decrease in the ratio between $\left[{ }^{11} \mathrm{C}\right] \mathrm{PIB}$ radioactivities in the antibody- and vehicle-injected hippocampi was observed (mean \pm SE; $1.05 \pm 0.02,0.96 \pm 0.01$, and $0.88 \pm 0.01$ before and 1 and 2 weeks after treatment, respectively; $F_{(2,4)}=$ 121.47 and $p<0.001$ for the main effect of time by repeatedmeasures ANOVA). In contrast, the right/left ratio of the PBR level indicated marked activation of glial cells in the antibodytreated hippocampus (Fig. 5D, left). Significantly, the magnitude of neuroinflammatory responses to antibody injection was well correlated with the amount of amyloid (Fig. $5 D$, right). The therapeutic efficacy of $\mathrm{A} \beta$ immunization was confirmed by direct microscopic examination of dissected brains, because marked reduction in amyloid load (Fig. $5 E, F, I$ ) and increase in hypertrophic microglia (Fig. 5G,H) were demonstrated. The difference in mean values of amyloid burden between the antibody-injected 


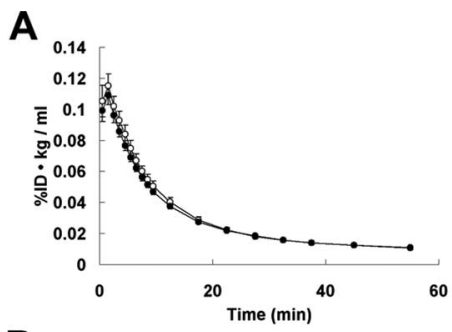

B
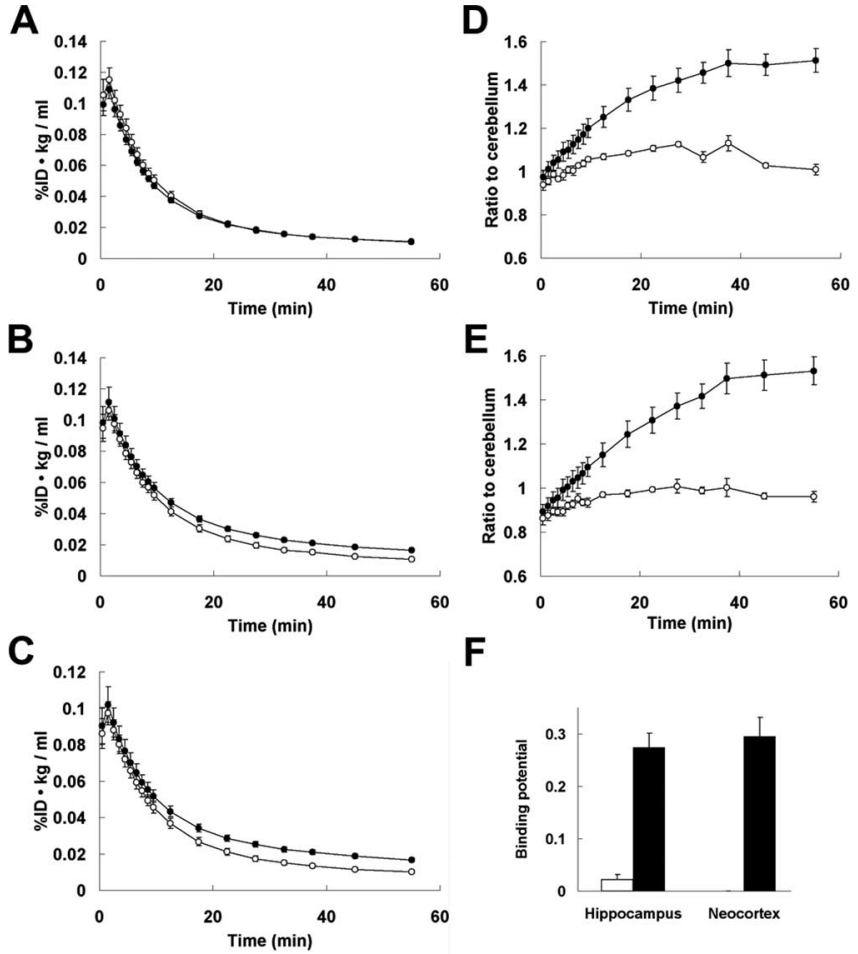

$\mathbf{F}$

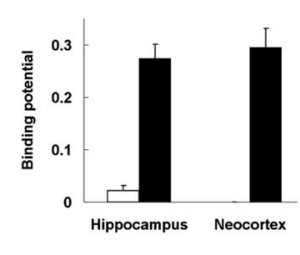

Figure 3. Association of regional radiotracer kinetics with brain amyloidosis in APP Tg mice. $\boldsymbol{A}-\boldsymbol{C}$, Time-radioactivity curves for the cerebellum $(\boldsymbol{A})$, hippocampus $(\boldsymbol{B})$, and neocortex $(\boldsymbol{C})$ acquired from dynamic PET scans for 20- to 22-month-old APP Tg (filled circles; $n=11$; age $=$ $21.4 \pm 0.30$ months) and age-matched WT (open circles; $n=6$; age $=21.7 \pm 0.76$ months) mice given injections of $\left[{ }^{11} \mathrm{C}\right] \mathrm{PIB}$. D, E, Target-to-cerebellum ratio of radioactivity in the hippocampus $(\boldsymbol{D})$ and neocortex $(\boldsymbol{E})$ at different time points. The ratio in Tg mice (filled circles) was progressively elevated toward $60 \mathrm{~min}$ after tracer administration, clearly contrasting with the near-steady state in WT mice (open circles) achieved from $\sim 15 \mathrm{~min}$ (significant main effects of time, region and genotype; time, $F_{(17,255)}=55.2, p<0.001$; region, $F_{(1,15)}=22.4, p<0.001$; genotype, $F_{(1,15)}=13.5, p<0.01 ; 2$-way, repeated-measures ANOVA). $\boldsymbol{F}$, Binding potential of the radioligand estimated by simplified reference tissue model. The tracer binding was pronouncedly increased in the hippocampus and neocortex of Tg mice (filled columns) compared with WT mice (open columns) (significant main effect of genotype; $F_{(1,10)}=32.8 ; p<0.001$; 2-way, repeated-measures ANOVA). Error bars represent SE.

and untreated hippocampi was $28.1 \%$, which was in good agreement with the mean decline $(34.4 \%)$ of binding potential in the PET analysis with $\left[{ }^{11} \mathrm{C}\right] \mathrm{PIB}$ over the period of 2 weeks. In contrast to $\mathrm{Tg}$ mice, passive $\mathrm{A} \beta$ immunization did not increase the levels of $\left[{ }^{18} \mathrm{~F}\right] \mathrm{FE}-\mathrm{DAA} 1106$ accumulation in WT mouse brains (supplemental Fig. 4A, $B$, available at www.jneurosci.org as supplemental material), supporting the association between initial $\mathrm{A} \beta$ burden and antibody-induced neuroinflammation. Finally, the preincubation of $\mathrm{Tg}$ brain sections with anti-A $\beta$ antibody (experimental procedure is described in supplemental Methods, available at www.jneurosci.org as supplemental material) did not markedly attenuate the in vitro radiolabeling of amyloid plaques with $\left[{ }^{11} \mathrm{C}\right] \mathrm{PIB}$ (supplemental Fig. 4C,D, available at www. jneurosci.org as supplemental material), and therefore intracranially injected antibody is unlikely to interfere with the binding of radiotracer to amyloid lesions. This observation is consistent with our in vivo PET data showing decline of $\left[{ }^{11} \mathrm{C}\right] \mathrm{PIB}$ binding between 1 and 2 weeks after antibody injection despite probable washout of antibody from the brain during this period.

\section{Effects of specific radioactivity of $\left[{ }^{11} \mathrm{C}\right]$ PIB on} amyloid detection

Because the present dose and specific radioactivity of $\left[{ }^{11} \mathrm{C}\right] \mathrm{PIB}$ administered to mice were higher than those in previous studies
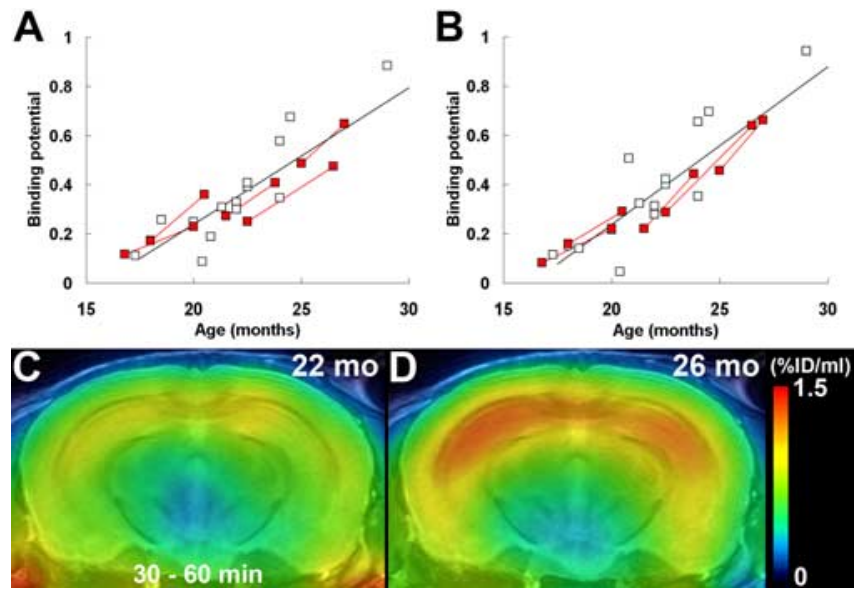

Figure 4. Ability of mouse PET system to capture progressive amyloidosis during aging. $A, B$, Scatterplots of binding potential versus age in the hippocampus $(\boldsymbol{A})$ and neocortex $(\boldsymbol{B})$ of the $\mathrm{Tg}$ mice (total, 25 scans; age, $21.9 \pm 0.62$ months; range, 16.8 -29.0 months), with the correlation of the two parameters being statistically significant in both regions (hippocampus, $R^{2}=$ 0.79 ; neocortex, $R^{2}=0.79 ; p<0.001$, $t$ test). Black lines represent regression, and red elements indicate longitudinal analysis of the same individuals $(n=5)$. C, $\boldsymbol{D}$, Progression amyloid accumulation revealed by the substantial increase in tracer binding in the hippocampal formations of the same animal. PET images were generated by averaging dynamic scan data at $30-60 \mathrm{~min}$ after tracer injection and were merged onto the MRI template. mo, Month.

(Klunk et al., 2005; Toyama et al., 2005), we postulated that these parameters likely affected the sensitivity of plaque detection in $\mathrm{Tg}$ mouse brains. Accordingly, PET scans were performed for the same animal by varying the ID and specific radioactivity, as exemplified in the case given two PET scans 1 week apart (Fig. $6 A-D)$. Lowering the ID of the radiotracer and reducing its specific radioactivity by the addition of cold ligand resulted in profound loss of signal-to-noise ratio and reduction in binding potential in the hippocampus and neocortex (Fig. 6E), along with insensitivity for detecting moderately intense clustered amyloid plaques, as was confirmed by ex vivo autoradiography and histochemical assay performed 1 week after the second PET measurement (Fig. 6C,D). Similarly, two other cases also exhibited a significant decline in binding potential when injected with tracer, the radioactivity concentration of which was diminished in advance by radioactive decay over $\sim 1.5 \mathrm{~h}$. In addition, another series of Tg mice undergoing multiple PET scans 1-2 weeks apart demonstrated that attenuation of binding potential also occurred by decreasing the specific radioactivity of the tracer from $\sim 200$ to $\sim 20 \mathrm{GBq} / \mu \mathrm{mol}$ while the ID was fixed at $\sim 30 \mathrm{MBq}$ (Fig. $6 E$ ), although additional decline of specific radioactivity to $\sim 0.2 \mathrm{GBq} /$ $\mu \mathrm{mol}$ did not induce further dramatic reduction in binding potential (Fig. 6E). Taking these observations together, it is likely that detection of relatively immature amyloid lesions, which are diffusely distributed in the mouse forebrain, is highly sensitive to the specific radioactivity of $\left[{ }^{11} \mathrm{C}\right] \mathrm{PIB}$ in a range from 20 to 200 $\mathrm{GBq} / \mu \mathrm{mol}$, and a subset of mouse plaques, which are large in size and/or form dense clusters, can be captured by micro-positron emission tomography regardless of the specific radioactivity if it ranges from 0.2 to $200 \mathrm{GBq} / \mu \mathrm{mol}$.

Association between $\left[{ }^{11} \mathrm{C}\right] \mathrm{PIB}$ binding to amyloid and $\mathrm{N}$ - and C-terminal heterogeneity of $A \boldsymbol{\beta}$

To assess differences in the binding of $\left[{ }^{11} \mathrm{C}\right] \mathrm{PIB}$ between $\mathrm{AD}$ patients and APP Tg mice, we conducted a comparative in vitro autoradiographic analysis of postmortem $\mathrm{AD}$ brain and several different strains of Tg mice, including APP23, Tg2576, and PS-1/ 

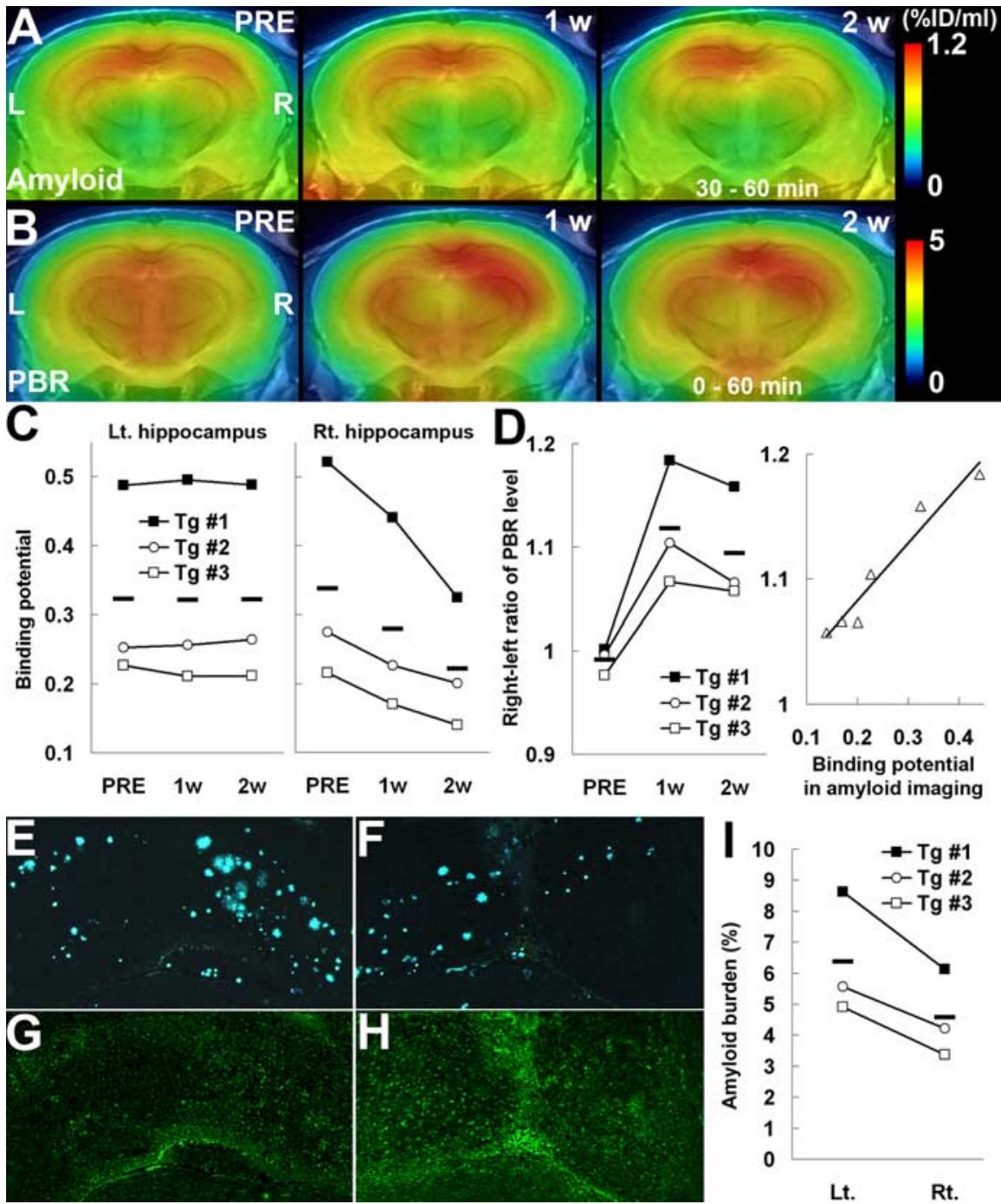

in amyloid imaging

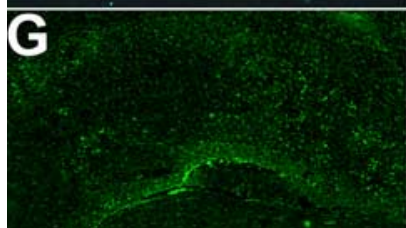

Figure 5. Amyloid elimination and glial activation during the course of anti-amyloid treatment as visualized by longitudinal PET scans. $\boldsymbol{A}, \boldsymbol{B}$, PET maps of $\left[{ }^{11} \mathrm{C}\right] \mathrm{PIB}(\boldsymbol{A})$ and $\left[{ }^{18} \mathrm{~F}\right] \mathrm{FE}-\mathrm{DAA} 1106(\boldsymbol{B})$ in a 20 -month-old APP Tg mouse (Tg \#3), generated by averaging dynamic data at 30-60 $\mathrm{min}(\boldsymbol{A})$ and $0-60 \mathrm{~min}(\boldsymbol{B})$, respectively, and superimposed on an MRI template. Images were obtained before (PRE; left), 1 week ( 1 w; middle), and 2 weeks ( 2 w; right) after passive $A \beta$ immunization. Vehicle alone and anti-A $\beta$ antibody were injected into the left and right hippocampi, respectively. $L$, Left; $R$, right. $C$, Time course of amyloid elimination quantified by multiple $\left[{ }^{11} \mathrm{C}\right] \mathrm{PIB}$ PET scans during the course of anti-amyloid treatment. Binding potential in the vehicle-injected hippocampus remained unaltered (left; $F_{(2,4)}=0.02$ and $p>0.05$ for main effect of time by repeated-measures ANOVA), whereas it was significantly reduced in the anti-A $\beta$ antibody-injected hippocampus (right; $F_{(2,4)}=7.56$ and $p<0.05$ for main effect of time by repeated-measures ANOVA). $\boldsymbol{D}$, Ratio between $\left[{ }^{18} \mathrm{~F}\right] \mathrm{FE}-\mathrm{DAA} 1106$ radioactivities (at $0-60$ min after the radiotracer administration) in antibody- and vehicle-injected hippocampi, showing a markedly elevated neuroinflammatory response triggered by antibody injection (left; $F_{(2,4)}=16.7$ and $p<0.05$ for main effect of time by repeated-measures ANOVA) and a close correlation between levels of neuroinflammation and amyloid at 1 and 2 weeks after treatment (right; $R^{2}=0.942$; $p<0.01, t$ test). The solid line represents regression. $\boldsymbol{E}-\boldsymbol{H}$, Double fluorescence labeling of amyloid (FSB; $\boldsymbol{E}, \boldsymbol{F})$ and microglia (Iba-1; $\boldsymbol{G}, \boldsymbol{H})$ in the left $(\boldsymbol{E}, \boldsymbol{G})$ and right $(\boldsymbol{F}, \boldsymbol{H})$ hippocampi of a $\mathrm{Tg}$ mouse (Tg \#1) at 2 weeks after immunization. $\boldsymbol{I}$, Load of FSB-positive amyloid in the hippocampus, indicating a significant left-right difference ( $p<0.05, t$ test). Horizontal bars in graphs represent mean values. Lt., Left; Rt., right.

APP double-Tg mice (Figs. 7, 8, first and second columns from the left). Although the brains of APP23 and Tg2576 mice at 23 months of age exhibited intense radiolabeled spots, the abundance of $\left[{ }^{11} \mathrm{C}\right] \mathrm{PIB}$-labeled plaques in these animals was much lower than that in the $\mathrm{AD}$ brain. Moreover, amyloid plaques in the brain of an 8-month-old PS-1/APP Tg mouse were not intensely radiolabeled with $\left[{ }^{11} \mathrm{C}\right] \mathrm{PIB}$ compared with other brain samples. We then measured the amounts of soluble and insoluble $\mathrm{A} \beta$ species in these mouse brain tissues by sandwich ELISA (ex- perimental procedure is described in supplemental Methods, available at www. jneurosci.org as supplemental material). The highest levels of detergent- and formic acid-extractable $\mathrm{A} \beta$ were observed in the APP23 mouse, and the amounts of such insoluble $\mathrm{A} \beta$ in Tg2576 and PS-1/ APP Tg mice were comparable to each other (supplemental table, available at www.jneurosci.org as supplemental material). Thus, the intensity of $\left[{ }^{11} \mathrm{C}\right] \mathrm{PIB}$ radiolabeling was not simply correlated with the levels of insoluble $A \beta$.

In search of specific $A \beta$ subtypes intimately related to the accumulation of $\left[{ }^{11} \mathrm{C}\right] \mathrm{PIB}$, the brain sections used for in vitro autoradiography were immunostained with antibodies against $A \beta 40$ and $\mathrm{A} \beta 42$. In the mouse brains, radioactive signals were colocalized with amyloid plaques that were doubly positive for $\mathrm{A} \beta 40$ and $\mathrm{A} \beta 42$, whereas the vast majority of plaque lesions in the $\mathrm{AD}$ brain were $A \beta 40$ negative and $A \beta 42$ positive (Fig. 7 ). These findings led to the supposition that C-terminal heterogeneity of $A \beta$ may not be critically responsible for the formation of $\left[{ }^{11} \mathrm{C}\right]$ PIB binding sites. We also immunohistochemically examined $\mathrm{N}$-terminal modification of $\mathrm{A} \beta$ using autoradiography sections (Fig. 8A-T). Notably, the localization and abundance of $\mathrm{A} \beta \mathrm{N} 3$ pyroglutamate-immunoreactive plaques were in good agreement with those of $\left[{ }^{11} \mathrm{C}\right] \mathrm{PIB}$ signals. Unlike $\mathrm{A} \beta \mathrm{N} 3$ pyroglutamate, unmodified $A \beta N 1 D$ was abundantly present in all brain sections examined here and did not show overt association with $\left[{ }^{11} \mathrm{C}\right] \mathrm{PIB}$ radiolabeling. Quantitative analysis of the $\mathrm{A} \beta$ burden and in vitro $\left[{ }^{11} \mathrm{C}\right] \mathrm{PIB}$ signal intensity also demonstrated that the radiotracer binding significantly correlated with the load of $\mathrm{A} \beta \mathrm{N} 3$-pyroglutamate but not with the depositions of $A \beta 40, A \beta 42$, and $A \beta N 1 D$ (Fig. $8 U, W$ ).

To assess whether $A \beta N 3$-pyroglutamate provides primary binding components for $\left[{ }^{11} \mathrm{C}\right] \mathrm{PIB}$, we assayed in vitro binding of $\left[{ }^{11} \mathrm{C}\right] \mathrm{PIB}$ to fibrils of $\mathrm{A} \beta \mathrm{N} 3$-pyroglutamate and $A \beta N 1 D$ assembled in the same condition (experimental procedure is given in supplemental Methods, available at www. jneurosci.org as supplemental material). High-level binding of ligands to $\mathrm{A} \beta \mathrm{N} 3$-pyroglutamate compared with $A \beta N 1 D$ was observed using $\left[{ }^{11} \mathrm{C}\right] \mathrm{PIB}$ at subnanomolar to nanomolar concentrations, which are equivalent to those in PET studies (supplemental Fig. 5A, available at www.jneurosci.org as supplemental material), and a two-site model applied to Scatchard plot demonstrates that $B_{\max }$ and $B_{\text {max }} / K_{\mathrm{D}}$ for the high-affinity component formed in $A \beta N 3$-pyroglutamate are five and four times larger than those in $A \beta N 1 D$, respectively (supplemental Fig. $5 B$, available at www.jneurosci.org as supplemental material). 

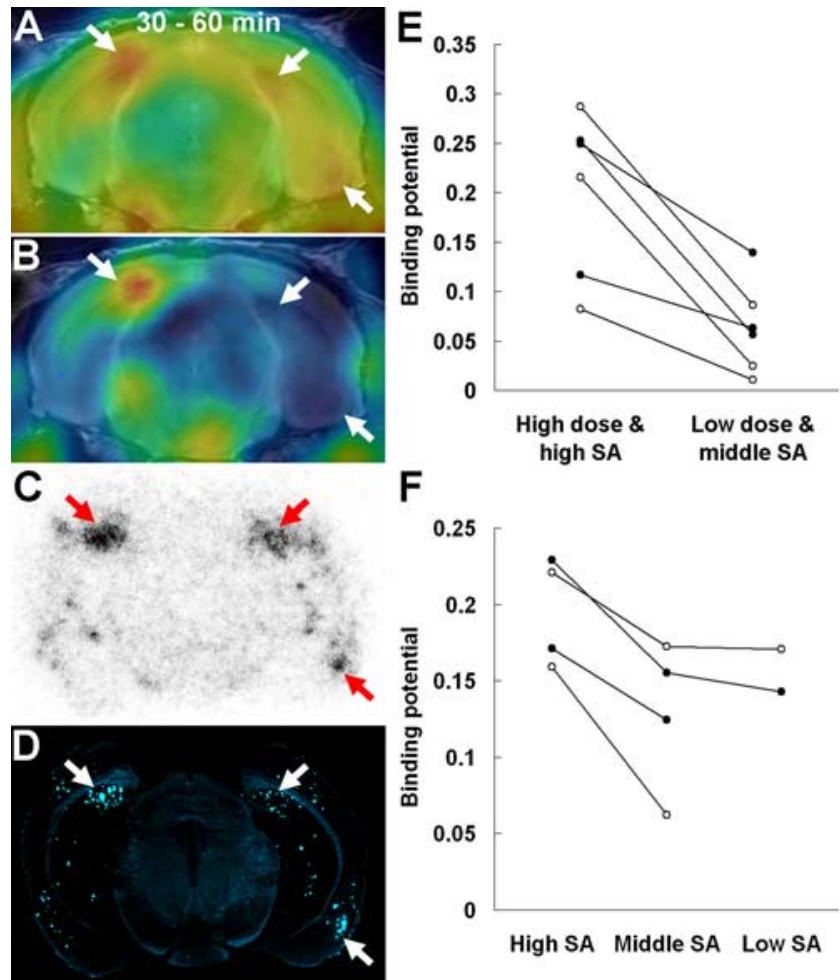

High SA Middle SA Low SA

Figure 6. Contribution of specific radioactivity $(S A)$ and ID of the radioligand to sensitive in vivo detection of amyloid plaques in APP Tg mice. $A$, PET image of a 20-month-old Tg mouse at $30-60$ min after administration of [ $\left.{ }^{11} \mathrm{C}\right] \mathrm{PIB}$ with high $\mathrm{SA}(\sim 200 \mathrm{GBq} / \mu \mathrm{mol})$ and high dose ( $\sim 37 \mathrm{MBq}$ ). The image was overlaid on the MRI template. Intense spots were found in the bilateral medial hippocampi and right entorhinal cortex (arrows). B, Merged PET and MR image of the same mouse acquired after administration of the tracer with middle $S A$ ( $\sim 20 \mathrm{GBq}$ ) $\mu \mathrm{mol}$ ) and low dose ( $\sim 3.7 \mathrm{MBq}) .(\mathbf{C}, \mathbf{D}$, Ex vivo autoradiography using the same mouse showing tracer localization at $30 \mathrm{~min}$ after administration $(\boldsymbol{C})$ and subsequent fluorescence staining of the autoradiographic sample using nonradioactive BTA-1 (D). Arrows indicate clusters of amyloid lesions corresponding to intense spots in $\boldsymbol{A}$. $\boldsymbol{E}$, Comparison of binding potential in the hippocampus (filled circles) and neocortex (open circles) of three Tg mice determined by PET scans with high-SA ( $\sim 200 \mathrm{GBq} / \mu \mathrm{mol})$, high-dose ( $30 \mathrm{MBq})$ and middle-SA ( $20 \mathrm{GBq} /$ $\mu \mathrm{mol})$, low-dose ( $\sim 3 \mathrm{MBq}$ ) tracers. $\boldsymbol{F}$, Comparison of binding potential in the hippocampus (filled circles) and neocortex (open circles) of two Tg mice obtained from PET data with high-SA ( $\sim 200 \mathrm{GBq} / \mu \mathrm{mol})$, middle-SA $(\sim 20 \mathrm{GBq} / \mu \mathrm{mol})$, and low-SA $(\sim 0.2 \mathrm{GBq} / \mu \mathrm{mol})$ tracers. The injected dose of the tracer was $\sim 30 \mathrm{MBq}$ in all measurements. Data from the same individuals in the graphs are connected by solid lines.

\section{Discussion}

The present work provides the first explicit evidence that an imaging probe, which has been applied in humans, is capable of noninvasively visualizing amyloid accumulation in living animal models. This permits a comparative evaluation of amyloidogenic processes in humans and mice using the same quantitative indices and thus assists the mechanistic understanding of amyloid pathogenesis in both species. In addition, the utility of a longitudinal PET study in quantitatively assessing alterations of amyloid levels as a function of age and in response to treatment is demonstrated for the first time, suggesting that amyloid imaging technology can successfully serve as an objective diagnostic and outcome measure for preclinical and clinical research. It is also noteworthy that the high-affinity binding sites in mouse amyloid that are much less abundant than those in human senile plaques could be captured by radiotracer with high specific radioactivity. Because the high-affinity component is the putative major source of radioactive signals in human PET studies, our strategies to increase specific radioactivity may contribute to the establish- ment of an animal system for predicting radiotracer binding in $\mathrm{AD}$ brains.

Because PET measurements require a very small amount of imaging agent compared with nonradioactive approaches, our current methodology offers a safe tool for monitoring brain amyloid in mice without overt toxicity. This advantage is also of particular significance, because prominent pharmacological effects of injected amyloid-binding tracers on the formation of amyloid (Lee, 2002; Masuda et al., 2006) are unlikely in PET studies. In fact, the regression slope in the scatterplot for measured amyloid levels against age (Fig. 4A,B) did not differ between mice undergoing single- and two-scan protocols (e.g., 0.060 and 0.061 per month, respectively, in the hippocampus). Thus, the present observations suggest that PET imaging of amyloid permits robust preclinical evaluation of therapeutic strategies for modifying the pathological course of $\mathrm{AD}$ and potentially provides a quantitative outcome measure of such treatments in clinical trials.

As confirmed here, the benefits of a multiscan, multitracer PET study in the same individual include a high statistical power, and the analysis of three Tg mice was indeed sufficient to statistically examine the effects of $A \beta$ immunization on amyloid load and inflammatory response (Fig. $5 C, D$ ). Moreover, the nearsimultaneous use of two different radiotracers, $\left[{ }^{11} \mathrm{C}\right] \mathrm{PIB}$ and $\left[{ }^{18} \mathrm{~F}\right] \mathrm{FE}-\mathrm{DAA} 1106$, has revealed that the magnitude of glial activation after immunization is closely associated with the amount of $A \beta$ amyloid. Excessive neuroinflammation may induce neurotoxic insults, as exemplified by the occurrence of meningoencephalitis in those who received $\mathrm{A} \beta$ vaccination (Nicoll et al., 2003; Orgogozo et al., 2003). Additionally, our recent investigation in a mouse model of neurofibrillary tangles using tritiated DAA1 106 has indicated that microglial overactivation in AD and other tauopathy brains could lead to accelerated tau pathogenesis and neuronal loss (Yoshiyama et al., 2007). Hence, the present result implies that therapeutic intervention should be initiated at an unadvanced stage of amyloid pathology to minimize adverse effects and supports the utility of $\left[{ }^{18} \mathrm{~F}\right] \mathrm{FE}-\mathrm{DAA} 1106$ in conjunction with $\left[{ }^{11} \mathrm{C}\right] \mathrm{PIB}$ in optimizing treatment protocols.

The present data also indicate that the specific radioactivity of the radioligand significantly contributes to the detectability of amyloid lesions developed in mouse brains by increasing amyloid-specific signals relative to the background associated with free and nonspecifically bound tracers. Our in vitro autoradiographic assay demonstrated a substantial difference in the intensity of $\left[{ }^{11} \mathrm{C}\right] \mathrm{PIB}$ radiolabeling between the brains of $\mathrm{AD}$ patient and APP Tg mouse strains, in line with the indication by a previous study (Klunk et al., 2005) that the concentration of specific binding sites available $\left(B_{\max }\right)$ in mice doubly transgenic for PS-1 and APP at 6-15 months of age is much lower than that in $\mathrm{AD}$ brains. From the present work, we can assume that amyloidrelated-specific signals are detectable if they exceed $10-20 \%$ of the background, and given that the $B_{\max }$ value in PS-1/APP double-Tg mice is 1000 -fold lower than that in $\mathrm{AD}$ patients, as estimated previously (Klunk et al., 2005), the threshold of the specific radioactivity for sensitive detection of amyloid in these mice (producing a bound-to-free ratio $>0.2$ ) exists at $\sim 74 \mathrm{GBq} /$ $\mu \mathrm{mol}$, according to calculation using the following parameters: $B_{\max }$ in $\mathrm{AD}$ brains, $\sim 1 \mu \mathrm{M}$; dissociation constant $\left(K_{\mathrm{D}}\right)$ for PIB, $\sim 1 \mathrm{nM}$; ID of $\left[{ }^{11} \mathrm{C}\right] \mathrm{PIB}$ for obtaining quality micro-PET images, $\sim 37 \mathrm{MBq}$; levels of $\left[{ }^{11} \mathrm{C}\right] \mathrm{PIB}$ in the brain at $60 \mathrm{~min}$ after tracer injection, $\sim 1 \% \mathrm{ID} / \mathrm{ml}$. In our autoradiographic experiment, APP23 mice exhibited intense radiolabeling of amyloid compared with PS-1/APP double-Tg mice, indicating diversity of $B_{\max }$ for $\left[{ }^{11} \mathrm{C}\right] \mathrm{PIB}$ among different $\mathrm{Tg}$ strains. Although the PS-1 

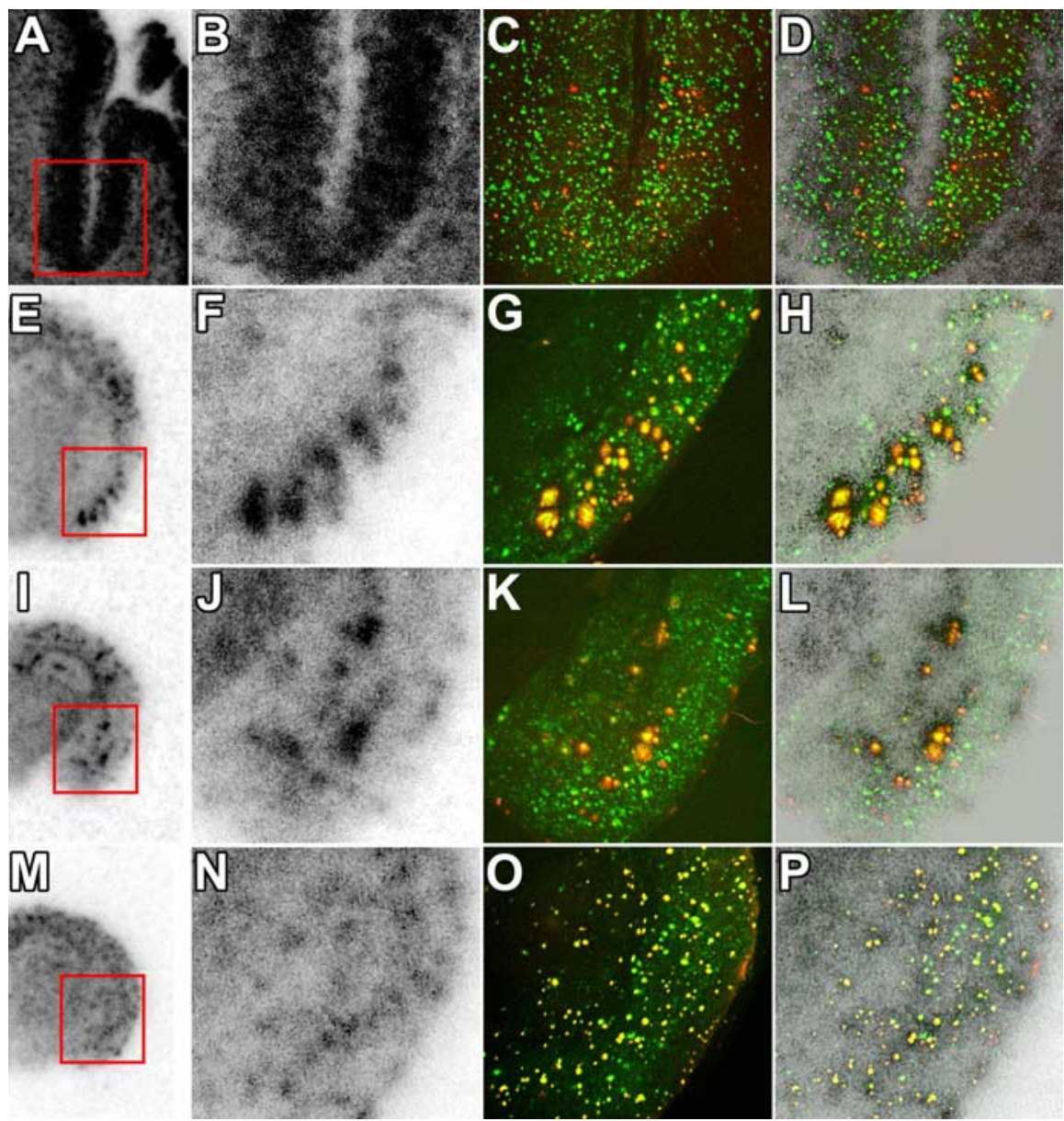

Figure 7. Association between in vitro radiolabeling of amyloid with $\left[{ }^{11} \mathrm{C}\right] \mathrm{PIB}$ and abundance of $A \beta 40$ and $A \beta 42$. Brain sections from the AD patient $(\boldsymbol{A}-\boldsymbol{D})$, 23-month-old APP23 mouse $(\boldsymbol{E}-\boldsymbol{H})$, 23-month-old Tg2576 mouse (I-L), and 8-month-0ld PS-1/APP double-Tg mouse $(\boldsymbol{M}-\boldsymbol{P})$ were used for autoradiography with $\left[{ }^{11} \mathrm{C}\right] \mathrm{PIB}$ (low-power and high-power autoradiograms are shown in the first and second columns from the left, respectively), and thereafter doubly immunostained for $A \beta 40$ (red in the third column) and $A \beta 42$ (green in the third column) with polyclonal anti-A $\beta 40$ and monoclonal anti- $A \beta 42$ antibodies. Colocalization of radiolabeling with $A \beta 40$ and $A \beta 42$ was assessed by merging autoradiograms with immunohistochemical data (shown in the fourth column). Similar double-immunofluorescence staining was obtained by using monoclonal anti- $A \beta 40$ and polyclonal anti-A $\beta 42$ antibodies (data not shown). Red squares indicate areas shown in magnified images.

Tg mice used for crossbreeding with Tg2576 mice in our study differ from the pre-established line (Duff et al., 1996; Klunk et al., 2005), it is conceivable that the detection threshold for amyloid in APP23 mice at 17-30 months of age is somewhat lower than 74 $\mathrm{GBq} / \mu \mathrm{mol}$. Notwithstanding this consideration, the present in vivo data (Fig. 6) provide evidence that the detectability of APP23 mouse amyloid is highly sensitive to the specific radioactivity $(20-200 \mathrm{GBq} / \mu \mathrm{mol}$ ) of the tracer (except for a subset of $\mathrm{A} \beta$ deposits such as large-sized, dense-cored plaques). Likewise, detection of amyloid aggregates in Tg2576 mice may also be facilitated by using $\left[{ }^{11} \mathrm{C}\right] \mathrm{PIB}$ with high specific radioactivity. Toyama et al. (2005) documented that levels of radiotracer accumulation in Tg2576 and WT mice at 22 months of age were comparable, whereas the same research group has more recently reported increased retention of radiotracer (specific radioactivity, $\sim 20 \mathrm{GBq} /$ $\mu \mathrm{mol})$ in the neocortex of older ( $>28$ months) Tg mice (Cai et al., 2006). This finding is in agreement with the indication from our data that the intensity of in vitro radiolabeling of amyloid deposits in 23-month-old Tg2576 mice does not greatly differ from that in age-matched APP23 mice (Figs. 7, 8), suggesting that the threshold of specific radioactivity for sensitive detection of amyloid in Tg2576 mice at this age exists at $20-50 \mathrm{GBq} / \mu \mathrm{mol}$.
Our comparative analysis of human and mouse brain tissues supports the notion that the total amounts of insoluble $\mathrm{A} \beta$ in the brain do not necessarily correlate with the accumulation of $\left[{ }^{11} \mathrm{C}\right]$ PIB measured by positron emission tomography (Klunk et al., 2005), whereas molecular elements responsible for the formation of PIB binding sites, possibly including certain $\mathrm{A} \beta$ subtypes, non- $\mathrm{A} \beta$ components of amyloid, and secondary structures of $\mathrm{A} \beta$ fibrils, are yet to be identified. $\mathrm{A} \beta \mathrm{N} 3$ pyroglutamate, however, is one of the strong candidates for a primary constituent of high-affinity PIB binding sites, based on our present combined autoradiographic and immunohistochemical investigations (Fig. 8). In contrast to the fact that $\mathrm{A} \beta \mathrm{N} 3$-pyroglutamate is a major component of human $\mathrm{A} \beta$ amyloid (Saido et al., 1995), it was biochemically demonstrated that this $A \beta$ subtype is not abundant in Tg2576 mice despite high-level deposition of insoluble, $\mathrm{N}$-terminally unmodified $\mathrm{A} \beta$ and is detectable only when these animals became older than 23 months (Kawarabayashi et al., 2001), in general accord with our histological results. Because similar findings were also obtained by other research groups (Güntert et al., 2006), the levels of $\mathrm{A} \beta \mathrm{N} 3$-pyroglutamate are likely to provide a plausible explanation for the difference in $\left[{ }^{11} \mathrm{C}\right] \mathrm{PIB}$ binding between humans and mice. $\mathrm{A} \beta \mathrm{N} 3$-pyroglutamate is thought to be generated via an auxiliary enzymatic pathway involving monopeptidyl and dipeptidyl aminopeptidases and thus is a slow process closely dependent on aging unless the major pathway of $\mathrm{A} \beta \mathrm{deg}$ radation mediated by endopeptidases is fundamentally disturbed. We therefore postulate that acceleration of $\mathrm{A} \beta$ production as exemplified by PS-1/APP double-Tg mice may not promote development of "AD-like" plaques enriched with $\mathrm{A} \beta \mathrm{N} 3$-pyroglutamate and PIB binding sites and that it is still required for these mice to age to be useful animal models of amyloidosis suitable for in vivo PET imaging. Moreover, in vitro experiments revealed that $\mathrm{A} \beta \mathrm{N} 3$ pyroglutamate has a greater propensity to form amyloid aggregates compared with unmodified $\mathrm{A} \beta$ species, acting as a seed in the formation of A $\beta$ fibrils (He and Barrow, 1999; Schilling et al., 2006), which implies that intensification of $A \beta$ amyloid toward mature aggregates containing highly concentrated PIB binding sites is accelerated in the presence of $A \beta N 3$-pyroglutamate. Our pilot in vitro binding assay using synthetic filaments assembled from $\mathrm{A} \beta \mathrm{N} 3$-pyroglutamate and $\mathrm{A} \beta \mathrm{N} 1 \mathrm{D}$ has demonstrated that specific binding of $\left[{ }^{11} \mathrm{C}\right] \mathrm{PIB}$ at subnanomolar to nanomolar concentrations to $\mathrm{A} \beta \mathrm{N} 3$-pyroglutamate fibrils exceeded that to A $\beta 1-42$ by fourfold to fivefold (supplemental Fig. 5, available at www.jneurosci.org as supplemental material), providing additional evidence for the contribution of $\mathrm{A} \beta \mathrm{N} 3$-pyroglutamate to the primary PIB binding sites. It is noteworthy that $\mathrm{A} \beta \mathrm{N} 3$ pyroglutamate fibrils contain more high-affinity binding sites than do $\mathrm{A} \beta \mathrm{N} 1 \mathrm{D}$ fibrils assembled in the same condition, suggest- 

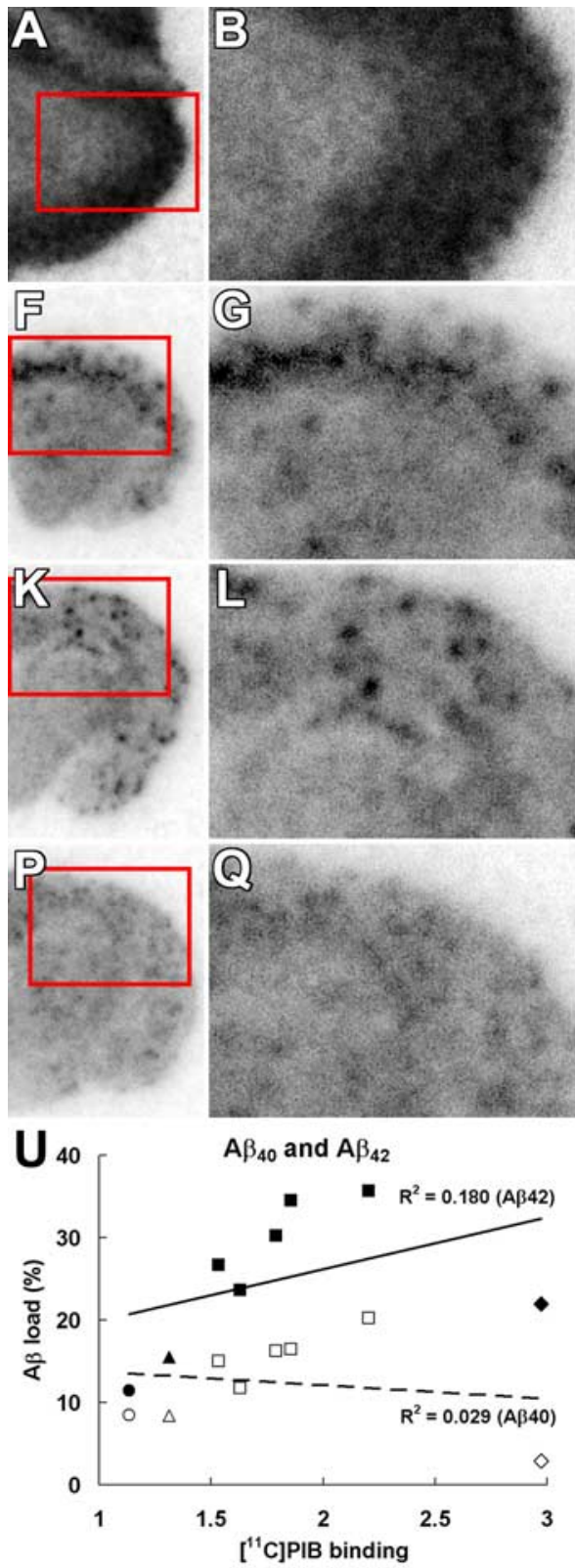
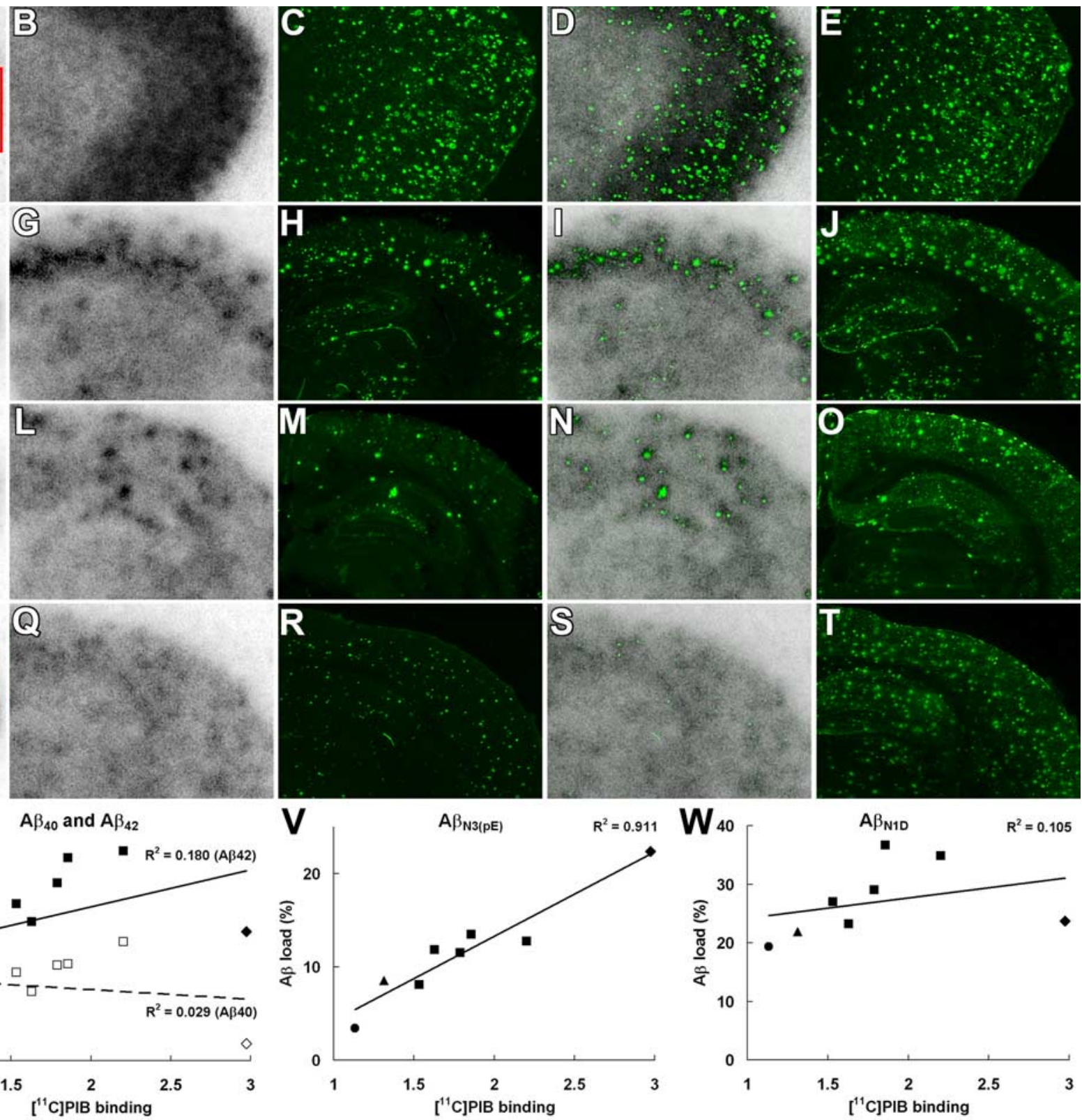

Figure 8. Search for $\mathrm{A} \beta$ subtypes accumulating in close relation to $\left[{ }^{11} \mathrm{C}\right] \mathrm{PIB}$ binding sites. $A-\boldsymbol{T}$, Association between in vitro radiolabeling of amyloid with $\left[{ }^{11} \mathrm{C}\right] \mathrm{PIB}$ and $\mathrm{N}$-terminal truncation/ modification of A $\beta$. Brain sections from the AD patient $(\boldsymbol{A}-\boldsymbol{E})$, 23-month-old APP23 mouse $(\boldsymbol{F}-\boldsymbol{J}), 23$-month-old Tg2576 mouse $(\boldsymbol{K}-\mathbf{0})$, and 8-month-old PS-1/APP double-Tg mouse $(\boldsymbol{P}-\boldsymbol{T})$ were used for autoradiography with $\left[{ }^{11} \mathrm{C}\right] \mathrm{PIB}$ (low-power and high-power autoradiograms are shown in the first and second columns from the left, respectively), and thereafter immunostained with polyclonal anti-A $\beta_{\mathrm{N} 3(\mathrm{pE})}$ antibody (third column). Colocalization of radiolabeling with $\mathrm{A} \beta_{\mathrm{N} 3(\mathrm{pE})}$ deposition was assessed by merging autoradiograms with immunohistochemical data (fourth column). Subadjacent sections were also immunolabeled with anti-A $\beta_{\mathrm{N} 1 D}$ antibody (fifth column). Red squares indicate areas shown in magnified images. $\boldsymbol{U}-\boldsymbol{W}$, Association of in vitro [ $\left.{ }^{11} \mathrm{C}\right] \mathrm{PIB}$ radiolabeling (normalized by intensity of nonspecific labeling) with areas occupied by $\mathrm{A} \beta 40\left(\boldsymbol{U}\right.$, open symbols), $A \beta 42$ (U, filled symbols), $A \beta_{\mathrm{N} 1(\mathrm{pE})}(\boldsymbol{V})$, and $\mathrm{A} \beta_{\mathrm{N} 1 \mathrm{D}}(\boldsymbol{W})$ immunolabeling in the cortex of the AD patient (diamonds) and APP23 (squares), Tg2576 (triangles), and PS-1/APP double-Tg (circles) mice. The intensity of [ $\left.{ }^{11} \mathrm{C}\right] \mathrm{PIB}$ signals was significantly correlated with A $\beta_{\mathrm{N} 3(\mathrm{pE})}$ labeling $\left(p<0.001, t\right.$ test), but not with the loads of other $A \beta$ species $\left(p>0.05, t\right.$ test). Solid lines represent regression for $A \beta 42(\boldsymbol{U}), A \beta_{\mathrm{N} 1(\mathrm{pE})}(\boldsymbol{V})$, and $A \beta_{\mathrm{N} 1 \mathrm{D}}(\boldsymbol{W})$, and the dashed line in $\boldsymbol{U}$ represents regression for $A \beta 40$.

ing the significance of $\mathrm{A} \beta \mathrm{N} 3$-pyroglutamate as a major source of target structures for $\left[{ }^{11} \mathrm{C}\right] \mathrm{PIB}$ positron emission tomography. The roles played by $\mathrm{A} \beta \mathrm{N} 3$-pyroglutamate in the formation of AD-like plaques should be further examined, such as by in vitro estimation of $B_{\max }$ and $K_{\mathrm{D}}$ for $\left[{ }^{11} \mathrm{C}\right] \mathrm{PIB}$ using $\mathrm{A} \beta \mathrm{N} 3$ pyroglutamate and $A \beta N 1 D$ aggregates at different stages of fibrillogenesis and comparison of in vivo $\left[{ }^{11} \mathrm{C}\right] \mathrm{PIB}$ binding and levels of $A \beta N 3$-pyroglutamate among various APP Tg mouse strains.

$\left[{ }^{11} \mathrm{C}\right] \mathrm{PIB}$ synthesized with high specific radioactivity is also potentially useful for human PET imaging. The threshold of spe- cific radioactivity for the detection of $\mathrm{AD}$ amyloid is estimated to be $\sim 0.1 \mathrm{GBq} / \mu \mathrm{mol}$, based on calculation with the following parameters: $B_{\max }$ in $\mathrm{AD}$ brains, $\sim 1 \mu \mathrm{M} ; K_{\mathrm{D}}$ for PIB, $\sim 1 \mathrm{nM}$; ID of $\left[{ }^{11} \mathrm{C}\right] \mathrm{PIB}, \sim 370 \mathrm{MBq}$; levels of $\left[{ }^{11} \mathrm{C}\right] \mathrm{PIB}$ in the brain at $60 \mathrm{~min}$, $\sim 0.002 \% \mathrm{ID} / \mathrm{ml}$. Accordingly, specific radioactivity in the common range for clinical PET studies $(\sim 37 \mathrm{GBq} / \mu \mathrm{mol})$ is unlikely to significantly affect the contrast between specific and background signals in $\mathrm{AD}$ patients. However, detectability of $\mathrm{A} \beta$ aggregates at earlier stages of AD pathogenesis may critically depend on the specific radioactivity of the tracer, provided that the 
concentration of PIB binding sites in this state between normal aging and prodromal dementia is markedly low compared with that in MCI and AD brains. This presumption could also be related to the previous finding that $A \beta N 3$-pyroglutamate in cored plaques is less abundant in brains showing earlier Braak stages (Güntert et al., 2006). Our present work thus suggests that pathological amyloidosis in nondemented subjects would be imaged by $\left[{ }^{11} \mathrm{C}\right] \mathrm{PIB}$ with high specific radioactivity and be more sensitively captured by a radioligand optimized using the animal PET imaging system proposed here.

Although several technical aspects need to be further improved, such as the spatial resolution of the scanner $(\sim 1.5 \mathrm{~mm})$ (Tai et al., 2005), our results rationalize the use of micro-positron emission tomography for elucidating molecular regulators of amyloid deposition and for proving concepts regarding the mechanisms of emerging approaches for therapeutic interventions (Dodel et al., 2003; Scarpini et al., 2003). This in vivo system also offers an efficient strategy to preclinically compare pharmacokinetic properties of multiple candidate amyloid probes in the same individual. In such a study, the distinct nature of amyloid aggregates in humans and mice is likely overcome by sensitively capturing the high-affinity components in mouse plaque using high-specific radioactivity ligands, allowing the findings in mice to be extrapolated to humans.

\section{References}

Bacskai BJ, Hickey GA, Skoch J, Kajdasz ST, Wang Y, Huang GF, Mathis CA, Klunk WE, Hyman BT (2003) Four-dimensional multiphoton imaging of brain entry, amyloid binding, and clearance of an amyloid-beta ligand in transgenic mice. Proc Natl Acad Sci USA 100:12462-12467.

Cai L, Ye D, Liow JS, Hong J, Cohen RM, Pike VW, Innis RB (2006) PET imaging of transgenic mice TG2576 using the beta-amyloid radioligand, [C-11]PIB. NeuroImage 31:T141-T142.

Dodel RC, Hampel H, Du Y (2003) Immunotherapy for Alzheimer's disease. Lancet Neurol 2:215-220.

Duff K, Eckman C, Zehr C, Yu X, Prada CM, Perez-tur J, Hutton M, Buee L, Harigaya Y, Yager D, Morgan D, Gordon MN, Holcomb L, Refolo L, Zenk B, Hardy J, Younkin S (1996) Increased amyloid- $\beta 42(43)$ in brains of mice expressing mutant presenilin 1. Nature 383:710-713.

Engler H, Forsberg A, Almkvist O, Blomquist G, Larsson E, Savitcheva I, Wall A, Ringheim A, Langstrom B, Nordberg A (2006) Two-year follow-up of amyloid deposition in patients with Alzheimer's disease. Brain 129:2856-2866

Güntert A, Döbeli H, Bohrmann B (2006) High sensitivity analysis of amyloid-beta peptide composition in amyloid deposits from human and PS2APP mouse brain. Neuroscience 143:461-475.

He W, Barrow CJ (1999) The A $\beta 3$-pyroglutamyl and 11-pyroglutamyl peptides found in senile plaque have greater $\beta$-sheet forming and aggregation propensities in vitro than full-length $A \beta$. Biochemistry 38:10871-10877.

Higuchi M, Iwata N, Matsuba Y, Sato K, Sasamoto K, Saido TC $(2005){ }^{19} \mathrm{~F}$ and ${ }^{1} \mathrm{H}$ MRI detection of amyloid b plaques in vivo. Nat Neurosci 8:527-533.

Hintersteiner M, Enz A, Frey P, Jaton AL, Kinzy W, Kneuer R, Neumann U, Rudin M, Staufenbiel M, Stoeckli M, Wiederhold KH, Gremlich HU (2005) In vivo detection of amyloid-beta deposits by near-infrared imaging using an oxazine-derivative probe. Nat Biotechnol 23:577-583.

Hsiao K, Chapman P, Nilsen S, Eckman C, Harigaya Y, Younkin S, Yang F, Cole G (1996) Correlative memory deficits, $A \beta$ elevation, and amyloid plaques in transgenic mice. Science 274:99-102.

Ichise M, Liow JS, Lu JQ, Takano A, Model K, Toyama H, Suhara T, Suzuki K, Innis RB, Carson RE (2003) Linearized reference tissue parametric imaging methods: application to $\left[{ }^{11} \mathrm{C}\right] \mathrm{DASB}$ positron emission tomography studies of the serotonin transporter in human brain. J Cereb Blood Flow Metab 23:1096-1112.

Ikonomovic MD, Abrahamson EE, Isanski BA, Debnath ML, Mathis CA, Dekosky ST, Klunk WE (2006) X-34 labeling of abnormal protein aggregates during the progression of Alzheimer's disease. Methods Enzymol 412:123-144.
Kametani F, Usami M, Tanaka K, Kume H, Mori H (2004) Mutant presenilin (A260V) affects Rab8 in PC12D cell. Neurochem Int 44:313-320.

Kawarabayashi T, Younkin LH, Saido TC, Shoji M, Ashe KH, Younkin SG (2001) Age-dependent changes in brain, CSF, and plasma amyloid $\beta$ protein in the Tg2576 transgenic mouse model of Alzheimer's disease. J Neurosci 21:372-381.

Klunk WE, Engler H, Nordberg A, Wang Y, Blomqvist G, Holt DP, Bergstrom M, Savitcheva I, Huang GF, Estrada S, Ausen B, Debnath ML, Barletta J, Price JC, Sandell J, Lopresti BJ, Wall A, Koivisto P, Antoni G, Mathis CA, et al. (2004) Imaging brain amyloid in Alzheimer's disease with Pittsburgh compound-B. Ann Neurol 55:306-319.

Klunk WE, Lopresti BJ, Ikonomovic MD, Lefterov IM, Koldamova RP, Abrahamson EE, Debnath ML, Holt DP, Huang GF, Shao L, DeKosky ST, Price JC, Mathis CA (2005) Binding of the positron emission tomography tracer Pittsburgh compound-B reflects the amount of amyloid- $\beta$ in Alzheimer's disease brain but not in transgenic mouse brain. J Neurosci 25:10598-10606.

Lammertsma AA, Bench CJ, Hume SP, Osman S, Gunn K, Brooks DJ, Frackowiak RS (1996) Comparison of methods for analysis of clinical $\left[{ }^{11} \mathrm{C}\right]$ raclopride studies. J Cereb Blood Flow Metab 16:42-52.

Lee VM (2002) Amyloid binding ligands as Alzheimer's disease therapies. Neurobiol Aging 23:1039-1042.

Logan J, Fowler JS, Volkow ND, Wang GJ, Ding YS, Alexoff DL (1996) Distribution volume ratios without blood sampling from graphical analysis of PET data. J Cereb Blood Flow Metab 16:834-840.

Masuda M, Suzuki N, Taniguchi S, Oikawa T, Nonaka T, Iwatsubo T, Hisanaga S, Goedert M, Hasegawa M (2006) Small molecule inhibitors of $\alpha$-synuclein filament assembly. Biochemistry 45:6085-6094.

Mintun MA, Larossa GN, Sheline YI, Dence CS, Lee SY, Mach RH, Klunk WE, Mathis CA, DeKosky ST, Morris JC (2006) $\left[{ }^{11} \mathrm{C}\right] \mathrm{PIB}$ in a nondemented population: potential antecedent marker of Alzheimer disease. Neurology 67:446-452.

Nichols L, Pike VW, Cai L, Innis RB (2006) Imaging and in vivo quantitation of beta-amyloid: an exemplary biomarker for Alzheimer's disease? Biol Psychiatry 59:940-947.

Nicoll JA, Wilkinson D, Holmes C, Steart P, Markham H, Weller RO (2003) Neuropathology of human Alzheimer disease after immunization with amyloid- $\beta$ peptide: a case report. Nat Med 9:448-452.

Noguchi J, Suzuki K (2003) Automated synthesis of the ultra high specific activity of $\left[{ }^{11} \mathrm{C}\right]$ Ro $15-4513$ and its application in an extremely low concentration region to an ARG study. Nucl Med Biol 30:335-343.

Orgogozo JM, Gilman S, Dartigues JF, Laurent B, Puel M, Kirby LC, Jouanny P, Dubois B, Eisner L, Flitman S, Michel BF, Boada M, Frank A, Hock C (2003) Subacute meningoencephalitis in a subset of patients with $\mathrm{AD}$ after A $\beta 42$ immunization. Neurology 61:46-54.

Price JC, Klunk WE, Lopresti BJ, Lu X, Hoge JA, Ziolko SK, Holt DP, Meltzer CC, DeKosky ST, Mathis CA (2005) Kinetic modeling of amyloid binding in humans using PET imaging and Pittsburgh compound-B. J Cereb Blood Flow Metab 25:1528-1547.

Saido TC, Iwatsubo T, Mann DM, Shimada H, Ihara Y, Kawashima S (1995) Dominant and differential deposition of distinct $\beta$-amyloid peptide species, $\mathrm{A} \beta_{\mathrm{N} 3(\mathrm{pE})}$, in senile plaques. Neuron 14:457-466.

Sair HI, Doraiswamy PM, Petrella JR (2004) In vivo amyloid imaging in Alzheimer's disease. Neuroradiology 46:93-104.

Sato K, Higuchi M, Iwata N, Saido TC, Sasamoto K (2004) Fluorosubstituted and ${ }^{13} \mathrm{C}$-labeled styrylbenzene derivatives for detecting brain amyloid plaques. Eur J Med Chem 39:573-578.

Scarpini E, Scheltens P, Feldman H (2003) Treatment of Alzheimer's disease: current status and new perspectives. Lancet Neurol 2:539-547.

Schilling S, Lauber T, Schaupp M, Manhart S, Scheel E, Böhm G, Demuth HU (2006) On the seeding and oligomerization of pGlu-amyloid peptides (in vitro). Biochemistry 45:12393-12399.

Shoghi-Jadid K, Small GW, Agdeppa ED, Kepe V, Ercoli LM, Siddarth P, Read S, Satyamurthy N, Petric A, Huang SC, Barrio JR (2002) Localization of neurofibrillary tangles and beta-amyloid plaques in the brains of living patients with Alzheimer disease. Am J Geriatr Psychiatry 10:24-35.

Sturchler-Pierrat C, Abramowski D, Duke M, Wiederhold KH, Mistl C, Rothacher S, Ledermann B, Bürki K, Frey P, Paganetti PA, Waridel C, Calhoun ME, Jucker M, Probst A, Staufenbiel M, Sommer B (1997) Two amyloid precursor protein transgenic mouse models with Alzheimer disease-like pathology. Proc Natl Acad Sci USA 94:13287-13292.

Styren SD, Hamilton RL, Styren GC, Klunk WE (2000) X-34, a fluorescent 
derivative of Congo red: a novel histochemical stain for Alzheimer's disease pathology. J Histochem Cytochem 48:1223-1232.

Suzuki K, Inoue O, Hashimoto K, Yamasaki T, Kuchiki M, Tamate K (1985) Computer-controlled large scale production of high specific activity $\left[{ }^{11} \mathrm{C}\right]$ RO 15-1788 for PET studies of benzodiazepine receptors. Int J Appl Radiat Isot 36:971-976.

Tai YC, Ruangma A, Rowland D, Siegel S, Newport DF, Chow PL, Laforest R (2005) Performance evaluation of the microPET focus: a third-generation microPET scanner dedicated to animal imaging. J Nucl Med 46:455-463.

Toyama H, Ye D, Ichise M, Liow JS, Cai L, Jacobowitz D, Musachio JL, Hong J, Crescenzo M, Tipre D, Lu JQ, Zoghbi S, Vines DC, Seidel J, Katada K, Green MV, Pike VW, Cohen RM, Innis RB (2005) PET imaging of brain with the $\beta$-amyloid probe, $\left[{ }^{11} \mathrm{C}\right] 6-\mathrm{OH}-\mathrm{BTA}-1$, in a transgenic mouse model of Alzheimer's disease. Eur J Nucl Med Mol Imaging 32:593-600.

Verhoeff NP, Wilson AA, Takeshita S, Trop L, Hussey D, Singh K, Kung HF, Kung MP, Houle S (2004) In-vivo imaging of Alzheimer disease $\beta$-amyloid with $\left[{ }^{11} \mathrm{C}\right]$ SB-13 PET. Am J Geriatr Psychiatry 12:584-595.
Wilcock DM, DiCarlo G, Henderson D, Jackson J, Clarke K, Ugen KE, Gordon MN, Morgan D (2003) Intracranially administered anti-A $\beta$ antibodies reduce $\beta$-amyloid deposition by mechanisms both independent of and associated with microglial activation. J Neurosci 23:3745-3751.

Yoshiyama Y, Higuchi M, Zhang B, Huang SM, Iwata N, Saido TC, Maeda J, Suhara T, Trojanowski JQ, Lee VM (2007) Synapse loss and microglial activation precede tangles in a P301S tauopathy mouse model. Neuron 53:337-351.

Zhang MR, Suzuki K (2005) Sources of carbon which decrease the specific activity of $\left[{ }^{11} \mathrm{C}\right] \mathrm{CH}_{3} \mathrm{I}$ synthesized by the single pass $\mathrm{I}_{2}$ method. Appl Radiat Isot 62:447-450.

Zhang MR, Maeda J, Ogawa M, Noguchi J, Ito T, Yoshida Y, Okauchi T, Obayashi S, Suhara T, Suzuki K (2004) Development of a new radioligand, FN-(5fluoro-2-phenoxyphenyl)-N-(2-[ $\left.{ }^{18} \mathrm{~F}\right]$ fluoroethyl-5-

methoxybenzyl)acetamide, for pet imaging of peripheral benzodiazepine receptor in primate brain. J Med Chem 47:2228-2235. 